\title{
The Potato Tuberworm: A Literature Review of Its Biology, Ecology, and Control
}

\author{
Silvia I. Rondon
}

Published online: 7 January 2010

(C) The Author(s) 2009. This article is published with open access at Springerlink.com

\begin{abstract}
The potato tuberworm, Phthorimaea operculella (Zeller), is a worldwide pest of solanaceous crops especially devastating to potatoes. Adults mate and lay eggs in foliage or tubers throughout the growing season, preferring foliage over tubers. When foliage has naturally or artificially senesced and/or tubers are accessible, they deposit eggs in or near the eye buds. The larvae mine leaves, stems, and petioles causing irregular galleries, and excavate tunnels through tubers. Foliar damage to the potato crop usually does not result in significant yield losses but infested tubers may have reduced marketability and losses in storage may be up to $100 \%$ especially in non-refrigerated systems. The greatest risk of tuber damage occurs immediately before harvest while the crop is left in the field prior to digging; additional damage may occur in storage, if conditions are not maintained properly. Potatoes that are left in the field for any length of time can become infested. The pest is difficult to control and growers rely extensively on the use of insecticides and a variety of cultural practices. After harvest, the insect may continue to develop on tubers or volunteer plants remaining in the field as well as on other solanaceous plants. Incorporation of host plant resistance together with insecticides and appropriate biological and cultural practices may provide the best management options. This review addresses $P$. operculella bionomics, including origins, distribution, host range, life cycle and life stage behavior; seasonal dynamics; abiotic factors; cultural, biological, and chemical control methods; and host plant resistance.
\end{abstract}

\section{S. I. Rondon $(\bowtie)$}

Hermiston Agricultural Research and Extension Center,

Crop and Soil Science, Oregon State University,

Hermiston, OR, USA

e-mail: silvia.rondon@oregonstate.edu
Resumen La palomilla de la papa Phthorimaea operculella (Zeller) es una plaga importante de cultivos de solanáceas en todo el mundo pero especialmente devastadora para la papa. Los adultos se aparean y ponen huevecillos en follaje o en tubérculo a lo largo del ciclo de cultivo, con preferencia de follaje sobre los tubérculos. Cuando el follaje senesce natural o artificialmente y/o los tubérculos están accesibles, las polillas depositan sus huevos en o cerca de los ojos de las yemas. Las larvas hacen minas en las hojas, los tallos y en peciolos causando galerías irregulares, y excavan túneles en los tubérculos. El daño al follaje del cultivo usualmente no resulta en pérdidas significativas de rendimiento, pero los tubérculos infestados pueden tener una reducción en el mercado y las pérdidas en el almacén pueden llegar hasta el $100 \%$ especialmente en sistemas no refrigerados. El mayor riesgo de daño en los tubérculos se presenta inmediatamente antes de la cosecha mientras el cultivo está en el campo antes de ser cosechado y transportado. Se puede presentar daño adicional en el almacén si las condiciones no se mantienen apropiadamente. Las papas que se quedan en el campo por tiempo prolongado pueden ser infestados. La plaga es difícil de controlar y los productores confían extensivamente en el uso de insecticidas y en una variedad de prácticas culturales. Después de la cosecha, el insecto puede continuar su desarrollo en tubérculos o en plantas voluntarias que permanecen en el campo, así como en otras solanáceas. La incorporación de resistencia en la planta hospedante junto con insecticidas y prácticas culturales y biológicas apropiadas pudieran proporcionar las mejores opciones de manejo. Esta revisión menciona la bionómica de $P$. operculella, incluyendo su origen, distribución, hospederos, ciclo de vida y el comportamiento de acuerdo al estadío de su vida; dinámica temporal; factores abióticos; métodos de control cultural, biológico y químico; y resistencia de la planta hospedante. 
Keywords Control · Insects · Integrated pest management . Lepidoptera $\cdot$ Potato $\cdot$ Potato tubermoth .

Phthorimaea operculella $\cdot$ Tuber damage

\section{Potato Tuberworm: Pest of Worldwide Importance}

The potato tuberworm, Phthorimaea operculella (Zeller) (Lepidoptera: Gelechiidae), is considered one of the most important potato pests worldwide because of its close relationship with its host, high adaptability to daily and seasonal changes, high reproductive potential, and economic damage (Bacon 1960a; Foot 1974a, 1979; Haines 1977; Shelton and Wyman 1979a, b; Briese 1986; Herman et al. 2005). Phthorimaea operculella is a cosmopolitan pest of solanaceous crops and weeds including potato, Solanum tuberosum L. (Fenemore 1988; Das and Raman 1994; Gilboa and Podoler 1995; Coll et al. 2000; Keller 2003). While foliar damage to the potato crop does not usually result in significant yield losses (Graft 1917), infested tubers may reduce marketability and damage can be magnified in storage, especially in non-refrigerated systems (Arnone et al. 1998). In the Middle East, P. operculella infestation can range between 1 and $65 \%$ in the field and stored potatoes (Fadli et al. 1974; Al-Ali et al. 1975), while in India, P. operculella is responsible for about 1 to $12.5 \%$ and $70 \%$ infestation in the field and storage, respectively (Lall 1949; Nirula 1960; Nirula and Kumar 1964; Gubbaiah and Thontadarya 1977; Chauhan and Verma 1991). In the U.S. Pacific Northwest, control of P. operculella is critical because potatoes are mostly stored and tubers infested with live larvae are considered unmarketable (there is a zero level of tolerance for live $P$. operculella larva in fresh and processed potatoes). The pest is very difficult to control and over the years growers have relied extensively on the use of insecticides (Foot 1974b) and a wide variety of cultural practices (Foot 1974a, 1976a; Shelton and Wyman 1979b; Clough et al. 2008). The pest infests potato plants throughout the growing season; larvae mine leaves, stems, petioles, and excavate tunnels through potato tubers which is considered the typical damage. When foliage is available, larvae penetrate the leaves and they can reach the stems. After the potato is harvested, the insect may continue to develop on tubers or volunteer plants remaining in the field including other solanaceous plants such as tomatoes (Gilboa and Podoler 1995; Coll et al. 2000). Cannon (1948) and Traynier (1975) suggested the preference of the moth for green foliage. When tubers are available, the adults deposit eggs in or near the eye buds (Fletcher 1914; Graft 1917; Rondon et al. 2007); thus, the greatest risk of getting tuber damage occurs immediately before harvest while the crop is left in the field awaiting digging. Potatoes that are left in the field for any length of time can become infested (Rondon et al. 2009). Incorporation of host plant resistance together with insecticides and appropriate biological and cultural practices, such as covering hills, irrigation, and limitation of exposure time in the field, may provide the best management options (Rondon et al. 2009). This review paper includes the following aspects of $P$. operculella biology, ecology and control: bionomics, including origins, distribution, host range, life cycle and behavior of each life stage; seasonal dynamics; control methods, including cultural, biological, and chemical control. The host plant resistance component is also discussed.

\section{Origins, Distribution, and Host Range}

Phthorimaea operculella was described in 1873 as Gelechia operculella (Zeller 1873). The genus was revised in 1902 and 1931 and assigned to the genus Phthorimaea in 1964 (Meyrick 1902; Povolny 1964). Although two other species of tuberworm can be found, Tecia solanivora (Povolny), restricted to Central and Northwest South America, and Symmestrischema plaesiosema (Turner), found in South America, Southeast Australia, and Philippines (Keller 2003; Barragan 2005), all the discussion presented in this review paper will focus on P. operculella because of its economic importance and widespread distribution.

Phthorimaea operculella likely originated in Western South America along with its main host, the potato (Graft 1917; Balachowsky and Real 1966). In the mid 1800's, $P$. operculella was reported as a potato pest when tuber damage was found in Tasmania, New Zealand, and Australia (Berthon 1855). In South Central Asia, $P$. operculella was introduced in 1906 to Bombay, India, from Italy (Lefroy 1907). In the mid-70's, P. operculella was introduced to Iraq through imported potato (Whilshire 1957; Al-Ali et al. 1975); in Russia, P. operculella was reported for the first time in the early 1980's (Zagulyaev 1982). Currently, P. operculella can be found in tropical and subtropical countries in South, Central, and North America, Africa, Australia, and Asia (Flint 1986; Rothschild 1986; Kroschel and Koch 1994); now it can be found in almost all potato production areas worldwide (Fig. 1). In the U.S., the potato tuberworm has been reported in California, Arizona, Florida, Texas, Maryland, Virginia (Radcliffe 1982), Colorado, North Carolina, South Carolina, New York, North Dakota (Chittenden 1913), Oregon, Washington and Idaho (Jensen et al. 2005; Rondon et al. 2007). Medina and Rondon (2008) studied the geographically based population structure across the U.S. The authors hypothesized that there are three defined genetic clusters that corresponded with northwestern, south central, and northeastern P. operculella populations. They suggested that the Appalachian Mountains 
- Distribution of PTW

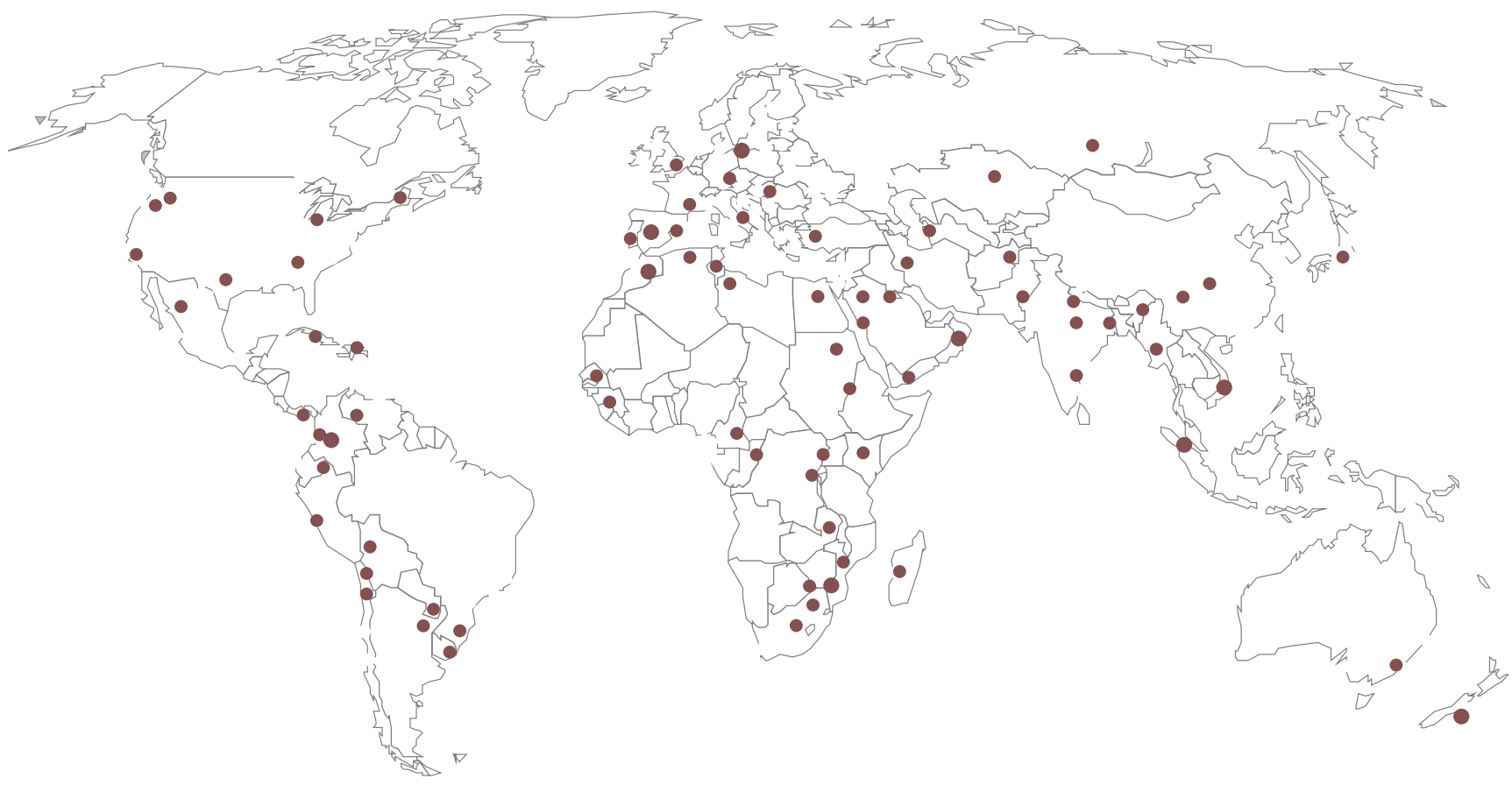

Fig. 1 Phthorimaea opeculella distribution around the world. Credits. S.Rondon (SmartDraw)

may act as a geographic barrier isolating eastern from western $P$. operculella sub-populations; similarly, the Rocky Mountains could be isolating the northwestern and south central tuberworm populations.

Although $P$. operculella is primarily a pest of potato, it can also be found in other solanaceous plants such as eggplant (Solanum melongena L.), tomato (Solanum lycopersicum L.), black nightshade (S. nigrum L.), silverleaf nightshade (S. elaegnifolium Cav.), chili pepper (Capsicum frutescens L.), tobacco (Nicotiana tabacum L.), cape gooseberry (Physallis peruviana L.), field groundcherry (Physalis mollis D.), prickly nightshade (S. torvum Sw.), jimson weed (Datura stramonium L.), P. angulata L., and Brugmansia suavellens Bersch (Shands et al. 1938; Bartoloni 1951; Gubbaiah and Thontadarya 1977; Trivedi and Rajagopal 1992). Cunningham (1969) also included the genera Physalis, Fabina, Hyoscyamus, Lycium and Nicandra as hosts of P. operculella. While P. operculella can be found in all crops and weeds listed above, field studies have shown that $P$. operculella only reproduce when feeding on potato, tomato and eggplant (Chittenden 1913; Morris 1933; Attia and Mattar 1939; Broodryk 1971; Meisner et al. 1974; Das and Raman 1994; Kroschel 1995); in the laboratory, $P$. operculella was found to feed on tomato, eggplant, and tobacco (Gubbaiah and Thontadarya 1975). In the U.S. Pacific Northwest, tuberworm feed and reproduce only in potatoes (Rondon et al. 2007). It is well noted that early behavior of first instars is critical for establishing in a suitable host plant (Varela and Bernays 1988); thus, not surprisingly, food source availability and quality is critical in $P$. operculella establishment and success.

\section{Biology of the Pest: Importance of Abiotic Factors in the Ecological Success of the Potato Tuberworm}

The biology of $P$. operculella has been studied extensively all over the world (Langford 1932; Langford and Cory 1932; Attia and Mattar 1939; Lall 1949; Mukherjee 1949; Bartoloni 1951; Manickavasagar 1953; Koizumi 1955; El-Sherif 1961; Stanev and Kaitazov 1962; Doreste and Nieves 1968; Yathom 1968; Broodryk 1970, 1971; Santorini 1971; Ono et al. 1972; Salama et al. 1972; Ono and Saito 1973; Al-Ali et al. 1975; Cardona and Oatman 1975; Fenemore 1977; Gubbaiah and Thontadarya 1977; Haines 1977; Fenemore 1978; Brits 1979; Fenemore 1979; Choe et al. 1980; Shelton and Wyman 1980; Chauhan and Verma 1985; Briese 1986; Chauhan and Verma 1991; Trivedi and Rajagopal 1992; Rondon et al. 2007; Dŏgramaci et al. 2008). Other $P$. operculella work includes detailed morphological studies carried out by Mukherjee (1949) and continued by 
Bartoloni (1951) and Brits (1979); and mass-rearing methods (Finney et al. 1944; Finney 1947; Platner and Oatman 1968; Wearne 1971; Platner and Oatman 1972a; Etzel 1985; Chi and Getz 1988; Makee and Saour 1997). Some details will be briefly described below.

Phthorimaea operculella has four life stages: adult, egg, larva and pupa. Adults are small moths (approximately $0.94 \mathrm{~cm}$ long) with a wingspan of approximately $1.27 \mathrm{~cm}$. Forewings have dark spots (2-3 dots on males; " $\mathrm{X}$ " on females) (Chauhan and Verma 1991; Rondon et al. 2007; Rondon and Xue 2010) (Fig. 2). Both pairs of wings have fringed edges. Moths can crawl through soil cracks or burrow short distances through loose soil to find tubers and deposit eggs. Copulation can take place 16 to $20 \mathrm{~h}$ after adult emergence; the duration of copulation ranges between 85 to 200 min (Gubbaiah and Thontadarya 1977; Chauhan and Verma 1985; Makee and Saour 2001). Adults are normally inactive during the day and oviposition occurs at night (Attia and Mattar 1939; Broodryk 1970, 1971; Traynier 1975, 1983). Early literature considered that adults were poor fliers (Reed 1971; Foot 1979; Fenemore 1988); however, recent studies have shown that they can fly for over $5 \mathrm{~h}$ up to $10 \mathrm{~km}$ non-stop (Foley 1985) but they cannot fly at wind speeds in excess of about 5-6 m/s (Krambias 1976; Foley 1985). Adults do not oviposit in the soil if potato foliage is available (Cannon 1948; Traynier 1975). The number of eggs laid and their longevity is directly related to their nutrition (Trehan and Bagal 1944; Labeyrie 1957; Traynier 1983) and male age appears to play an important role in the ability of the males to mate (Makee and Saour 1999).

Eggs are $\leq 0.1 \mathrm{~cm}$ spherical, translucent, and range in color from white or yellowish to light brown. In the field,

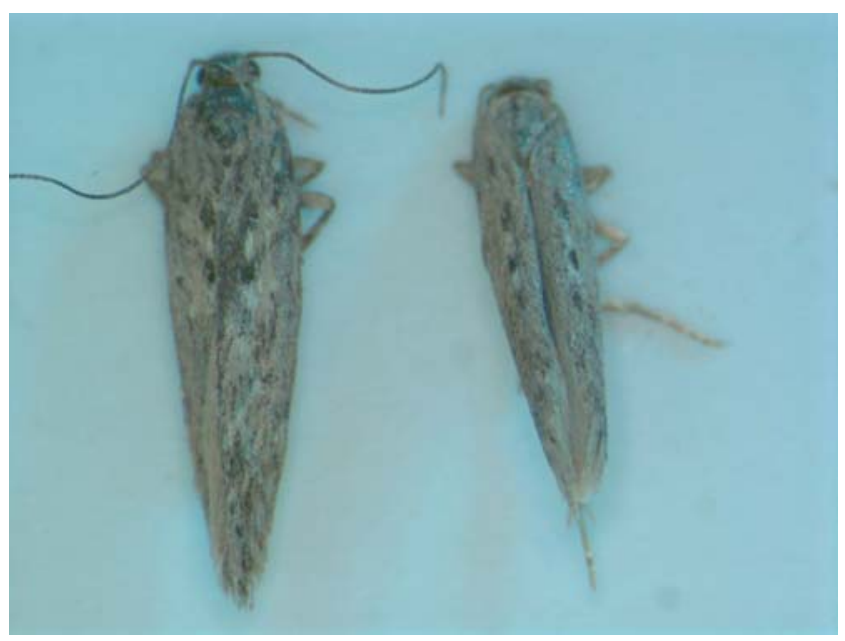

Fig. 2 The potato tuberworm, Phthorimaea operculella adults are small moths (approximately 3/8" long) with a wingspan of approximately $1 / 2$ "; forewings have dark spots (2-3 dots on males, right; " $\mathrm{X}$ " on females, left) females lay their eggs on foliage, soil and plant debris, or exposed tubers (Rondon et al. 2007); however, foliage was the preferred oviposition substrate (Varela and Bernays 1988). In laboratory studies, $P$. operculella eggs were laid singly or in batches (2-20 eggs) around buds, cracks, fissures or peeled potato skins (Al-Ali et al. 1975). The hatching time depends closely on temperature (Langford and Cory 1934; Ascerno 1991) (Table 1). Gubbaiah and Thontadarya (1977) indicated that in the field females laid eggs singly and rarely in groups of 3-5 eggs on either side of the leaf but close to the mid-rib. Under storage conditions $\left(\sim 7.2^{\circ} \mathrm{C}\right)$, eggs were laid singly or in groups of 3 to15 near the eye buds. Eggs can be widely distributed in the soil but greater numbers are found around the base of the plants than between rows of plants (Traynier 1975). Females can lay 38 to 290 eggs with an incubation period of 5 to 34 days (Trivedi and Rajagopal 1992). Van der Goot (1926) observed 4 to 5 days incubation period, while Al-Ali et al. (1975) reported 2.3 and 7.2 days at 33.3 and $20.9^{\circ} \mathrm{C}$, respectively (Al-Ali et al. 1975) (Table 1). Other authors reported a range between 3 to 9.9 days depending on temperature (Bartoloni 1951; Stanev and Kaitazov 1962; Verma 1967; Al-Ali et al. 1975). The upper critical temperature at which no eggs were laid was reported at $36^{\circ} \mathrm{C}$ (Attia and Mattar 1939).

Larvae are usually light brown with a characteristic brown head (Fig. 3). Mature larvae (approximately $0.94 \mathrm{~cm}$ long) may have a pink or greenish color. No sexual dimorphism is observed until the 3rd larval stage where incipient sexual structures are visible; in the 4th larval stage, males are distinguishable from females by the presence of two elongated yellowish testes in the 5th and 6th abdominal segment (Chauhan and Verma 1991). Length of time between instars is closely influenced by temperature. Moregan and Crumb (1914) reported 15 to 17 days as the larval period; others reported a range of 13 to 33 days (Graft 1917; Trivedi and Rajagopal 1992) (Table 1). Van der Goot (1926) observed 14 days total larval period. Langford and Cory (1932) reported normal larval activity (i.e. feeding, molting) from 11.1 to $39.4^{\circ} \mathrm{C}$. Larvae feed on leaves throughout the canopy but prefer the upper foliage; larvae mine the leaves, usually leaving the epidermal areas on the upper and lower leaf surface intact (Rondon, unpublished data). Larval feeding results in necrotic areas on leaves and leaf damage is unremarkably distinct but not always easy to find without careful scouting. Larvae also move via cracks in the soil to find tubers, thus exposed tubers are predisposed to tuberworm damage (Rondon et al. 2007) (Fig. 4). Larvae close to pupation drop from infested foliage to the ground and may burrow into the tuber to complete its life cycle. Ultimately, larvae will spin silk cocoons and pupate on the soil surface or in debris under the plant. 
Table 1 Developmental rate of $P$. operculella at various locations as presented by various authors

\begin{tabular}{lllllll}
\hline Source & Location & \multicolumn{2}{l}{ Duration (\# of days) } & & Mean temperature $\left({ }^{\circ} \mathrm{C}\right)$ \\
\cline { 3 - 6 } & & & Eggs & Larvae & Pupae & Adults (life span) \\
\hline Van der Goot 1926 & Unknown & 4.5 & 14.0 & 15.5 & $\mathrm{a}$ & $\mathrm{a}$ \\
Langford \& Cory 1932 & USA & 5.4 & 13.6 & 10.0 & $\mathrm{a}$ & 23.4 \\
Broodryk 1970, 1971 & South Africa & 4.3 & 12 & 6.4 & 14.3 & 25.0 \\
Santorini 1971 & Greece & 4.0 & 11.0 & 8.5 & 8.5 & 27.0 \\
Al-Ali et al. 1975 & Iraq & 3.8 & 12.6 & 7.2 & 4.5 & 28.2 \\
Gubbaiah \& Thontadarya 1977 & India & 5.0 & 14 & 6.5 & 6.6 & 23.0 \\
Chauhan \&Verma 1991 & India & 3.5 & 12 & 5.5 & 11.6 & 27.2 \\
DeBano et al, unpublished & USA & 7.2 & 15.5 & 12.5 & $\mathrm{a}$ & 22.2 \\
\hline
\end{tabular}

${ }^{a}$ not indicated in the paper

Occasionally $P$. operculella pupae can be found on the surface of tubers, most commonly associated with indentations on the tuber eyes, but usually are not found inside tubers (Rondon et al. 2007). Phthorimaea operculella pupae (approximately $0.84 \mathrm{~cm}$ long) are smooth and brown and often enclosed in a covering of fine sediment. There is a clear distinction between male and female pupae. Rondon and Xue (2010) evaluated the "scar" and the "width" method. Using the "scar" method, males can be recognized by the longer distance between the incision located between the 8th and 9th abdominal segment and the tip of the abdomen. There is also a gradual change in color eye pigmentation. This information can help estimate the age of the pupae. Based on eye pigmentation pupae are classified into newly formed pupa (yellowish in color, 1 to 2 day old pupae), followed by early red ( 3 day old), middle red (4 day old), late red to black eye pupa (5 to 6 day old) (Summers et al. 1982; Chauhan and Verma 1985, 1991). Some studies suggest that the pupal period is not fixed but depends on the temperature at which the larvae grew (Whiteside 1985). Moregan and Crumb reported 6 to 9 days as pupal period (Moregan and Crumb 1914). However, Graft (1917)

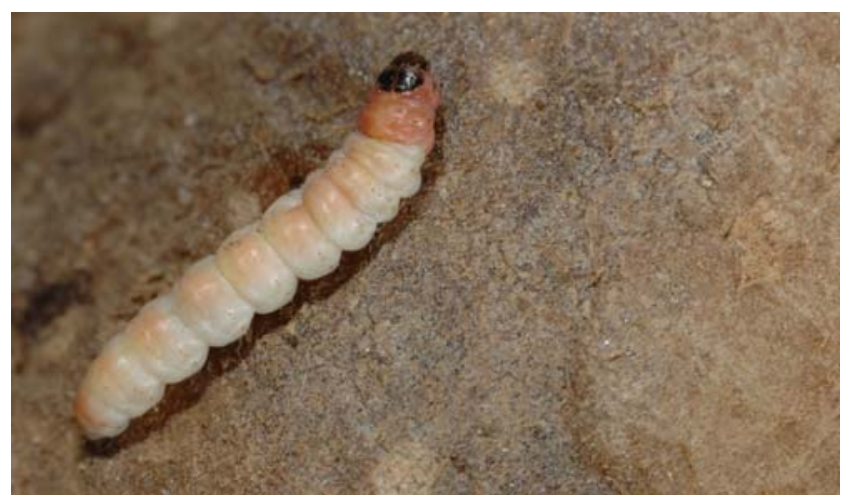

Fig. 3 Mature larvae (approximately 3/8" long) may have a pink or greenish color and brown collar head reported 13 to 33 days and Van der Goot (1926) observed 14 to 17 days pupal period (Table 1). Preliminary studies in Oregon indicated that $P$. operculella adults can potentially emerge from soil at depths up to $10.16 \mathrm{~cm}$ (Rondon, unpublished data). Once adults emerge, mating occurs, and within a few hours, females seek a potential host to lay their eggs on. Moths are fairly active at temperatures between 14.4 and $15.5^{\circ} \mathrm{C}$; at $11.1^{\circ} \mathrm{C}$ they can crawl but do not fly according to Langford and Cory (1934); however, in the U.S. Pacific Northwest, high number of moths were found in 2005 when temperatures were below freezing (Rondon et. al 2007).

Considering the duration period of each instar and its relationship to abiotic factors such as temperature, $P$. operculella can complete several generations per year. Chittenden reported two generations of $P$. operculella in summer and a third generation in storage (Chittenden 1912); Van der Goot found six to eight generations a year in tropical regions (Van der Goot 1926). French (1915) reported two generations in Australia, one in the winter and a second one on stored tubers. In Chile and the U.S., all stages of $P$. operculella were found throughout the year

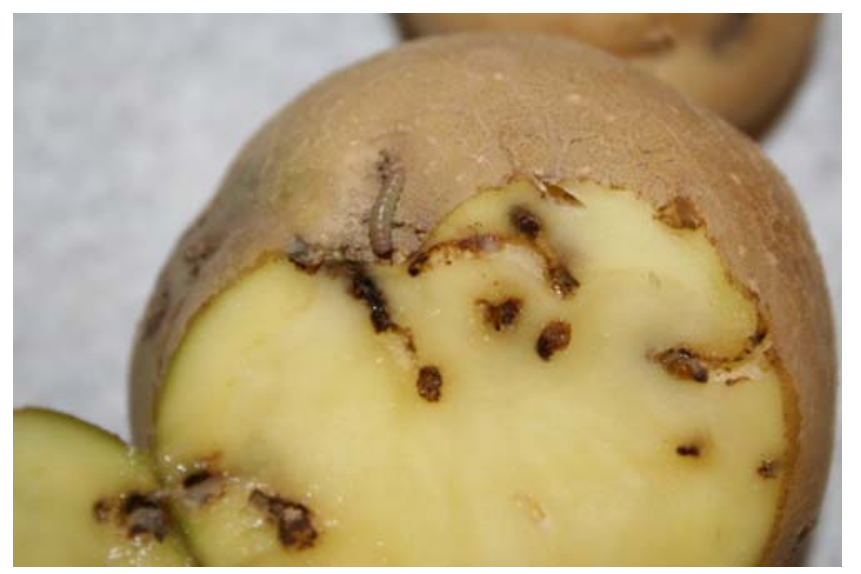

Fig. 4 Exposed tubers are predisposed to tuberworm damage 
with three to four generations (Graft 1917; Trivedi and Rajagopal 1992; Sporleder et al. 2004); thirteen generations per year were reported in India (Mukherjee 1949) and twelve in Iraq (Al-Ali et al. 1975). This information suggests a correlation between geographical location and number of $P$. operculella generations per year; locations with one crop per season will have 2 to 3 generations per year (i.e. U.S. Pacific Northwest, (Sporleder et al. 2008)), while locations with year-round crops will have several generations per year.

Since temperature plays a major role in insect growth and development, studies on developmental thresholds for pests of economic importance such as $P$. operculella are necessary to establish critical thresholds for selection of adequate control methods (Ascerno 1991; Legg et al. 2000; Sporleder et al. 2004). Phthorimaea operculella developmental threshold has been widely studied (Attia and Mattar 1939; Broodryk 1970a, Chauhan and Verma 1991; Davoud et al. 1999; Sporleder et al. 2004, 2008). Attia and Mattar (1939) determined the lower developmental threshold for eggs at $13.5^{\circ} \mathrm{C}$ while the upper developmental threshold for adults was $40^{\circ} \mathrm{C}$. Broodryk (1971) determined the developmental threshold of South Africa P. operculella eggs as $4.25^{\circ} \mathrm{C}$; this temperature is $1.2^{\circ} \mathrm{C}$ below the one reported by Attia and Mattar (1939) for Egyptian tuber moth. Sporleder et al. (2004) reported $11.0,13.5$ and $11.8^{\circ} \mathrm{C}$ developmental thresholds for egg, larva and pupa, respectively; in contrast, Davoud et al. (1999) reported theoretical developmental thresholds of $7.6,10.98$ and $7.79^{\circ} \mathrm{C}$ for egg, larval and pupal stage, respectively. Dŏgramaci and Rondon (unpublished data) have found that the minimum developmental threshold of egg, larval and pupal stages was between 5 and $8^{\circ} \mathrm{C}$ suggesting that this insect can survive the mild winters of the Pacific Northwest Columbia Basin. Differences in temperature suggest the remarkable adaptation of this insect to abiotic characteristics of any given area.

\section{Special Attention to Cold Temperatures}

In the Columbia Basin of the U.S. Pacific Northwest, trapping data from spring 2004 to fall 2005 showed that $P$. operculella males were present and active every week except one (in mid-January), with the highest numbers per trap occurring in December where the average temperature is around $-0.09^{\circ} \mathrm{C}$ (Rondon et al. 2007, 2008). Studies by Langford (1934) indicated that low temperatures retard and cause temporary cessation of $P$. operculella development not only physiologically but also due to the destructive effect of low temperatures on the food supply. In Israel, $P$. operculella first generation reached its peak in May or June (late spring, early summer) (Coll et al. 2000) and overlapping generations reached high numbers close to harvest which seems to be a characteristic of nondiapausing insects in favorable environments with continuous access to host plants (Yathom 1968, 1986, Coll et al. 2000; Sporleder et al. 2004). According to Whiteside (1985), P. operculella does not undergo diapause in South Africa (Broodryk 1971) or in the colder climate of central Europe (Povolny and Weismann 1958). One explanation of how this pest was able to survive the Columbia Basin winter conditions is that tuberworm eggs, larvae, and pupae survive in cull piles, potato tubers left in the soil after harvest and in volunteer potatoes (Shelton and Wyman 1980; Rondon et al. 2007; Dŏgramaci et al. 2008). "Warm" winters may also account for high $P$. operculella populations the following season (DeBano et al. 2010). Early studies in Maryland and Virginia (Underhill 1926; Langford 1934) indicated that $P$. operculella can survive sub-freezing temperatures which accounts for winter $P$. operculella populations. Several authors reported that larvae and pupae could potentially survive frost (Cory 1925); other studies indicated that all life stages of $P$. operculella were killed by exposure to $-6.6^{\circ} \mathrm{C}$ for $24 \mathrm{~h}$ (Langford and Cory 1932, 1934). Early studies by Langford in 1934 reported that $P$. operculella survived temperatures ranging from -11.6 to $-6.6^{\circ} \mathrm{C}$ but prolonged exposures to those temperatures were apparently fatal to all stages. Trivedi and Rajagopal (1992) found that pupae were the most tolerant to cold temperatures; however, Langford and Cory (1934) indicated that full-grown larvae appear to survive in the greatest numbers at low temperatures (Langford and Cory 1934). Dogramaci et al. (2008) indicated that with the exception of last (prepupal) instar larvae that are about to pupate and leave tubers before they freeze, larvae at most developmental stages remain inside tubers, and thus would likely be killed by frost. Eggs exposed to 1.6 to $4.4^{\circ} \mathrm{C}$ for four months failed to hatch (Langford and Cory 1932, 1934). Langford and Cory (1934) indicated that outbreaks of $P$. operculella in Virginia in 1925 and 1930 coincided with hot and dry years and the intensity of infestation vary in proportion to the amount of rainfall; they also indicated that humidity appeared to have a slight effect on the developmental period of all stages of P. operculella.

\section{Controlling the Potato Tuberworm}

Several approaches for the development of an integrated pest management system for $P$. operculella are available. However, considering that most of the economic damage by this insect occurs when the insect infests tubers, early attempts to control this pest should focus on cultural methods. Deeper seed planting, hilling the rows, irrigation and early harvest are a few of the methods suggested to prevent tuber infestation (Langford and Cory 1932; 
Langford 1933; Shelton and Wyman 1979a) since these methods discourage egg-laying moths from finding oviposition substrates. The use of chemicals, however, is still the main foundation of $P$. operculella control worldwide (Shorey et al. 1967; Bacon et al. 1972; Hofmaster and Waterfield 1972).

Monitoring the Potato Tuberworm Adult male moths are attracted by pheromone, concentrated quantities of the female "scent", impregnated in a rubber septum in the center of a sticky liner in the trap. According to Herman et al. (2005), two chemicals have been identified as the main component of $P$. operculella sex pheromone: (E4,Z7)tridecadienyl acetate (PTM1) (Roelofs et al. 1975) and (E4,Z7,Z10)-tridecatrienyl acetate (PTM2) (Persoons et al. 1976); both chemicals were synthesized, blended, and tested (Voerman and Rothschild 1978; Raman 1988). Since some other insects, including other Gelechiidae moths could be trapped in the sticky liners, they should be changed once a week for easy viewing of adult moths; lures should be changed monthly but may be used longer, depending on environmental conditions; at cooler temperatures the longevity of the lures increases (Rondon et al. 2007).

Pheromone traps are used to monitor populations in the field to help time insecticide applications (Herman et al. 2005). The relationship between pheromone trapping and pest infestation in the foliage and tubers can help determine the selection of appropriate integrated pest management methods. Several authors found a positive relationship between the number of trapped adults and the density of larvae in the foliage and tuber (Shelton and Wyman 1979a, b; Lall 1989); we did not find such a correlation (Rondon, unpublished data). Although treatment levels have not been established widely for $P$. operculella, California recommends a threshold of 15-20 moths per trap per night as a general threshold level. Something important to keep in mind is that $P$. operculella numbers vary highly from field to field and from area to area; thus, it is suggested that control management recommendations be based on fieldspecific information (Rondon et al. 2007) and standard thresholds should be used solely as reference. Growers in areas potentially impacted by $P$. operculella are encouraged to monitor insect numbers using pheromone traps (Rondon et al. 2007). Several researchers have tested different types of traps (Kennedy 1975; Bacon et al. 1976; Raman 1988; Salas et al. 1991; Tamhankar and Harwalkar 1994). In New Zealand, Herman et al. (2005) tested the use of water traps, which caught the greatest number of moths per trap as compared to the "DeSIRe" sticky traps (delta shaped), "A traps" (cylinder-shaped), and funnel traps. They concluded that the delta trap was the most suitable for commercial use. Coll et al. (2000) used pheromone traps plus poison bait placed on the ground at $50 \mathrm{~m}$ intervals in single rows. Based on Herman et al. (2005) findings, the recommendation in the U.S. Pacific Northwest has been to place at least one delta trap per potato field, beginning after canopy closure (Rondon et al. 2007). Note that soil type has an effect on the number of moths caught per trap; in Israel, almost twice as many moths were caught in pheromone traps located in sandy soil than in loess fields (Coll et al. 2000).

Cultural Control Some key aspects of the ecology of $P$. operculella are important in selecting best management practices to control this pest. How this pest is distributed in and within the plant and field can guide control efforts. The relationship between quality plant and insect preference helps choosing best control method. Succulent plants attract more tuberworm than wilting, non-irrigated plants (Yathom 1968), and the distribution of foliage damage within field crops tends to be non-random (Foot 1974a, 1976b, 1979) since $P$. operculella tends to concentrate on the edges of the field facing the prevailing winds in a band parallel to the edge (Foot 1979). Coll et al. (2000) found that larval density in foliage and tubers was higher at the margins of the field than in the center which is a typical characteristic of pests that move from area to area (Reed 1971; Foot 1979; Gilboa and Podoler 1995). Plants on the edges are exposed to wind and solar radiation that leads to drier conditions that are attractive to $P$. operculella females for oviposition (Meisner 1969; Meisner et al. 1974; Gilboa and Podoler 1995; Coll et al. 2000). Some experiments suggest that a low number of moths foraged beyond $100-250 \mathrm{~m}$ to infest tuber or plants (Cameron et al. 2002). In the U.S. Pacific Northwest most of the potatoes are vine-killed right before harvest, thus it is recommended that $P$. operculella control take place at or after vine-kill (Rondon et al. 2007).

There are several cultural methods that have been reported to reduce $P$. operculella population. These include the elimination of cull piles and volunteers, timing of vinekill, soil moisture at and after vine-kill, time between desiccation and harvest, rolling hills and covering hills, and cultivar selection (Rondon et al. 2007). In Tunisia, practices like deep seeding, hilling up, early harvest, irrigation until harvest, good sorting of tubers at harvest and rapid harvesting prevent tuber infestation (von Arx et al. 1987a; BenSalah and Aalbu 1992). Several biological and ecological studies support the effectiveness of one or more of these cultural practices.

Tubers naturally mature as the potato plant senesces; however, improved methods keep potato vines healthier and greener; in addition, tuber maturation can be artificially induced by killing the potato vines mechanically, chemically, or with a combination of both. All these activities have an impact on $P$. operculella population infestation. 
Field observations support the premise that $P$. operculella prefer green foliage to tubers to oviposit and feed upon, and when foliage starts to decline, tuber infestation naturally increases. Thus the time between desiccation and harvest is crucial. The longer the potatoes are left in the field after desiccation, the greater the likelihood of tuber infestation. Tuberworm moths and larvae are forced to go into the ground as vines are killed and, consequently, the risk of tuber damage increases (Rondon et al. 2007). Adults go into the soil via soil cracks to find shelter from the light and to lay their eggs on tubers, while larvae are forced there to find food. Tubers that are exposed or close to the surface are at high risk for tuberworm damage. Growers need to do everything possible to maintain more than $5 \mathrm{~cm}$ of soil over the tubers during the season (Rondon et al. 2007).

Female moths prefer dry soil for oviposition (Meisner 1969; Meisner et al. 1974) and survival of larvae increases with decreasing soil moisture content (Foot 1979). Therefore, keeping the soil moist via overhead irrigation to avoid cracks in the soil, particularly later in the season when vines are beginning to die, reduces $P$. operculella tuber infestation. Research has shown that irrigating daily with $0.25 \mathrm{~cm}$ through a center pivot irrigation system from vine kill until harvest decreased P. operculella tuber damage and did not increase fungal or bacterial diseases (Rondon et al. 2007; Clough et al. 2008). A possible explanation of the positive effect of daily irrigation application is that water closed soil cracks, reducing tuber access; thus tuberworm possibly died from lack of oxygen in the soil due to water saturation, and/ or their mobility was reduced by wet soil decreasing their ability to find a tuber to infest. According to Foot (1979), larval survival is inversely related to soil moisture and tuber depth. It also has been shown that exposed tubers are more prone to tuberworm infestation (von Arx et al. 1987a). Foot (1979) indicated that tuber infestation occurred 2-4 weeks before harvest and all infested tubers were covered with no more than $3 \mathrm{~cm}$ of soil.

Research has found that rolling of potato hills in sandy soil caused soil to slough off the hill, which resulted in increased $P$. operculella damage and therefore is not recommended in areas with sandy soils. Covering hills with $2.5-5.1 \mathrm{~cm}$ of soil immediately after vine-kill, which can be accomplished with a rotary corrigator, has been shown to significantly reduce tuber infestation (Rondon et al. 2007; Clough et al. 2008). Also, cull piles and volunteer potatoes should be eliminated to reduce overwintering stages, which are a source of next years' populations (Shelton and Wyman 1980).

Chemical Control Studies suggest that insecticides that are effective against foliar infestation by $P$. operculella may not prevent tuber infestation (Bacon 1960a, b; Bacon et al. 1971; Foot 1974a, 1976c, 1979; Hoffmaster 1959). In the early 80 's in Tunisia, foliar insecticide applications with deltamethrin prior to harvest did not reduce tuberworm infestation (von Arx et al. 1987b). In Israel, good control was achieved using Insect Growth Regulators (IGRs) in comparison to metamidophos applied at the lower part of the canopy (Berlinger 1992). In the U.S. Pacific Northwest, research has shown that applying insecticides at and after vine kill almost always reduced $P$. operculella damage in tubers (Rondon et al. 2007). As a reference, a list of products that have been found to be effective for control of $P$. operculella in Oregon and Washington can be found at http://insects.ippc. orst.edu/pnw/insects. This link is regularly updated.

Application of insecticides to reduce tuber damage is a very important issue. Gubbaiah and Thontadarya (1977) observed that the moths were more active during evening hours; during sunny days moths were found hiding on the undersurface of leaves; thus application should be in coordination with peak in insect activity. Trials in 2005 in the Columbia Basin suggested that the application of three insecticides (esfenvalerate, methamidophos, and methomyl) beginning at different intervals before vine kill, significantly reduced tuber damage, but there was no advantage in beginning control efforts earlier (4 weeks prior to vine-kill) than later (1 week prior to vine-kill). This information was generated for potatoes that were chemically killed down. Practices to be followed in fields that are allowed to slowly and naturally die down have not been adequately addressed but that situation poses a different question since tuber infestation could occur as the canopy opens slowly over a long time period (Rondon et al. 2007; Clough et al. 2008).

Biological Control Under current pest management schemes in potatoes, especially in locations with an intensive agricultural production system centered on frequent calendar sprays of broad spectrum insecticides, the impact of natural enemies on P. operculella is unknown (Koss 2003); in contrast, a lot of information regarding the biology and the potential of natural enemies (a.k.a. biological control agents) including parasitoids, predators, and diseases can be found in the literature. The advantage of using biological control agents is that they have no pre-harvest intervals, and are safer for application personnel, food supply and non-target organisms.

Parasitoids and Predators In Israel, Coll et al. (2000) reported five parasitic wasps and several predators of $P$. operculella. The parasitic wasps identified were Diadegma pulchripes (Kokujev), Temelucha decorate (Gravenhorst), both Ichneumonidae, Bracon gelechiae Ashmead (Braconidae), and two other unidentified Braconidae. The predators identified were Coccinella septempunctata Linnaeus (Coccinellidae), Chrysoperla carnea Stephens (Chrysopidae), Orius albidipennis (Reuter) (Anthocoridae), and four unidentified species of Formicidae (Coll et al. 
2000). Copidosoma koehleri Blanchard and Apanteles subandinus Blanchard are believed to be excellent parasitoids of P. operculella worldwide along with Trichogramma (Doutt 1947; Watmough et al. 1973; Annecke and Mynhardt 1974; Cardona and Oatman 1975; Whiteside 1980; Kfir 1981a; Whiteside 1981, 1985) along with Trichogramma (Flanders 1935, 1945; Klomp and Teerink 1962; Martson and Eartle 1973; Lewis et al. 1976; Kfir 1981b, 1983). In South America, Copidosoma and Apanteles wasps controlled $P$. operculella field populations (Redolfi and Vargas 1983). In Australia, A. subandinus Blanchard, Orgilus lepidus Muesebeck and Copidosoma desantisi Annecke and Mynhardt (=C. koehleri sensus) were reported in a 1979 survey. Other parasitoids like Tachinidae (Incamyia cuzcensis T.T. and Lixophaga diatraeae Towns), and more than 60 Hymenoptera (Braconidae, Encyrtidae, Eulophidae, Ichneumonidae, Mymaridae, Perilampidae, Pteromalidae, Scelionidae, and Trichogrammatidae) have also been described by several authors (Labeyrie 1959; Lloyd and Guido 1963; Jai Rao 1967; Rao 1967; Rao and Ramachandran-Nair 1967; Leong and Oatman 1968; Rao and Nagaraja 1968; Oatman et al. 1969; Lloyd 1972; Odebiyi and Oatman 1972; Cruickshank and Ahmed 1973; Callan 1974; Oatman et al. 1974; Oatman and Platner 1974; Cardona and Oatman 1975; Chundurwar 1977, 1978; Odebiyi and Oatman 1977; Mitchell 1978; Divakar and Pawar 1979; Franzman 1980; Sankaran and Girling 1980; Briese 1981; Flanders and Oatman 1982, 1987; Powers and Oatman 1984; Izhevskiy 1985; Horne 1990, 1993). Among all parasitoids listed, there are some ecological differences; for instance, while $C$. desantisi oviposits in the eggs, $A$. subandinus and $O$. lepidus prefer young $P$. operculella larvae (Platner and Oatman 1972a). In the U.S. Pacific Northwest, only two parasitoid wasp species have been collected from $P$. operculella although in small numbers: Habrobracon gelechiae and an unidentified specie OSAC \# 21138 (Rondon et al. 2007). However, in some instances, parasitism and predation has been estimated at $40 \%$ and $79 \%$, respectively (Coll et al. 2000). Level of parasitism was found higher in larvae feeding in the leaves (65\%) as compared to larvae infesting tubers (32\%) (Briese 1981), suggesting that parasitoids find it easier to encounter the host in exposed potato leaves rather than on tubers buried in the ground. Callan (1974) unsuccessfully tried to correlate parasitism and field damage; he indicated that since parasitism does not lead to instant mortality, it cannot provide immediate control, therefore raising some questions regarding the efficacy of the use of natural enemies. The studies of the culturing and mass producing of parasitoids conducted since the early 1970 's could potentially promote the increased use of natural enemies (Flanders 1930, Finney et al. 1944, Platner and Oatman 1968, 1972b). These and future studies will promote the benefits of using biological control either by artificial releases (i.e. inundative or inoculative) or conservation of natural enemies that can be used in combination with chemical control.

Microbial Control Insect diseases caused by bacteria, viruses, and nematodes have been developed as microbial pesticides to control insect pests not only in the field but also in the storage (Reed 1969, 1971; Reed and Springett 1971; Hunter 1973; Briese and Mende 1983; Alcázar et al. 1992; BenSalah and Aalbu 1992; Das et al. 1992; Raman 1994; Kroschel et al. 1996b; Lery et al. 1997; Roux and Baumgartner 1998; Setiawati et al. 1999). However, microbial control of $P$. operculella is not yet developed for massive commercial use although some authors have indicated the potential use of those pathogens in the future (Lacey and Arthurs 2005; Arthurs et al. 2008). In fact, some small scale tuberworm control by microbes has been already used successfully (Kroschel et al. 1996a, b; Sporleder et al. 2001, 2005; Sporleder 2003).

Little information has been reported on the activity of the $P$. operculella granulovirus (PoGV) in vivo (Hunter et al. 1975) or the history of the spread of the virus. Nevertheless, it seems that the granulovirus (GV) accompanied the tuberworm from its South America center of origin. The name of the virus derived from its granular appearance consisting on a single viral rod which enters $P$. operculella body by ingestion and from there it reproduces causing the death of the insect. A comprehensive study of this process was discussed by Reed (1971) in the early 70's and later by Sudeep et al. (2005). It is interesting that this GV, first isolated in the mid 1900's from a laboratory $P$. operculella population, was not reported to occur naturally in the field before the early 40's and 60's (Steinhaus 1945; Reed 1969, 1971; Reed and Springett 1971). In 1979, Foot reported two larval pathogens in field populations of $P$. operculella, including a $\mathrm{GV}$ virus and an unidentified bacterial disease (Foot 1979). In South Africa field populations of $P$. operculella were found infected with GV(Broodryk and Pretorius 1974). By the late 80's and early 90's GV was widely tested in the field. Ben Salah and Aalbu (1992) recommended the application of GV-water spray 2 weeks prior to harvest rather than GV-powder application since it was easier to apply as a water solution than as a powder. Results of the use of viruses in the field has been variable: close to $100 \%$ control was achieved in Western Australia (Reed and Springett 1971) while 53 to $85 \%$ infection rate was achieved using the same dosage in a similar location (Matthiessen et al. 1978). In this situation, weather conditions probably played an important role in the success of the use of the viruses although it was not thoroughly discussed by Reed and Springett or Matthiessen. Another explanation for this discrepancy may be the difference in susceptibility or the potential development of 
resistance to a GV strain between fields populations occurred in P. operculella Australia population. Timing of virus applications (Briese 1981; Briese and Mende 1981). Timing of virus applications (Reed 1971; Reed and Springett 1971), methods of application, concentration, and ultraviolet radiation can influence effectiveness of control (Kroschel et al. 1996a, b; Sporleder et al. 2001, 2005; Sporleder 2003).

The only bacterium evaluated to control $P$. operculella has been Bacillus thuringensis Berliner (B. thuringensis). This is a naturally occurring bacteria that produces crystal toxins (Beegle and Yamamoto 1992; Lacey et al. 2001) which cause lysis of the midgut epithelium. Two crystal proteins, Cry1A and Cry1B have been isolated under laboratory conditions and isolated from several subspecies including kurstaki, thuringensis, tolworthi, galleriae, kenyae and aizawai (Salama et al. 1995a, b). The lethal concentration $\left(\mathrm{LC}_{50}\right)$ varies according to subspecies and application method (i.e. dust versus liquid formulations) (Amonkar et al. 1979; Hamilton and Macdonald 1990; von Arx and Gebhardt 1990). Although commercial mixtures of $B t$ are being used successfully to control lepidopteran larvae (Harpaz and Wysoki 1984), its current use is primarily on small field organic farms (Broza and Sneh 1994), in laboratories and storage facilities. Repeated pre-harvest applications are required because $B t$ is degraded by ultraviolet light and rain (Awate and Naik 1979; Broza and Sneh 1994; Salama et al. 1995b). Also, post-harvest applications in non-refrigerated stored potatoes may be needed (von Arx et al. 1987a; Salama et al. 1995a; Kroschel and Koch 1996; Farrag 1998).

There is not much information regarding other beneficial agents such as the fungi Nosema which can cause up to $80 \%$ infection rate and cause shortening of larval life and lowering of reproduction capacity of adults (Allen and Brunson 1947). Other fungi such as Metarhizium anisopliae, Beauveria bassiana and Muscodor albus have potential for control of larvae (Hafez et al. 1997; Sewify et al. 2000; Worapong et al. 2001; Stinsen et al. 2003; Lacey and Arthurs 2005; Mercier and Smilanick 2005).

Parasitoids, predators, and pathogens can control $P$. operculella populations effectively under low input and conventional production systems if chemicals compatible with the biological control agents are chosen. As sustainable agricultural practices become more widely adopted, natural enemy communities will become increasingly on demand. Therefore, understanding the basis of natural interactions is an important step towards long-term balanced agroecosystem management.

Other novel ways to control $P$. operculella include the use of the inherited sterility technique. This technique has been suggested as an alternative control method to suppress
P. operculella populations (Makee and Saour 1997; Saour and Makee 1997; Makee and Saour 1999). The results, unfortunately, have been mixed. The use of gamma radiation applied to fully developed $P$. operculella pupae affected their reproductive potential and their behavior (Elbadry 1964); those effects are undesirable under the basic premise of the "sterile technique" (Knipling 1955) since this technique is a method of biological control, whereby millions of sterile insects are released. Insects released are normally male. The sterile males will compete with the wild males for female insects; if female mates with a sterile male then it will have no offspring reducing the next generation's population. Thus, keeping the behavior of wild populations is key in the success of this program.

\section{Infestation in Storage}

Potatoes should be stored at temperatures ranging between 7.2 to $10^{\circ} \mathrm{C}$ (University-California 2006). Since P. operculella does not develop at temperatures below $5^{\circ} \mathrm{C}$ (Al-Ali et al. 1975), it should not cause economic problems in cold storage (Roux et al. 1992; Keasar et al. 2005). In theory, it might be possible for the tuberworm to survive such temperatures which slow their developmental rate; however, eggs, larvae or pupae held in cold storage for long periods of time are incapacitated (Langford and Cory 1934). In developing countries, potatoes are stored in sheds, under trees or in uncooled warehouses (Hossain et al. 1994; Keasar et al. 2005). Tuberworm damage under those conditions can be devastating (up to $100 \%$ in some cases). Exposed tubers in the field serve as the primary source of infestation during storage (Gubbaiah and Thontadarya 1975). In developing countries, the majority of potato farmers pile the tubers in storage and cover them with potato vines which were infested with larvae in the field, and can then infest the stored tubers in storage (Gubbaiah and Thontadarya 1975). Well ventilated storage rooms that can be cooled through water evaporation plus the installation of insect nets should be added when possible to reduce storage problems (Ilangantileke et al. 1997). In North Africa, the rapid increase in population of $P$. operculella in the field prior to harvest results in heavy infestation during storage (Essamet et al. 1988; von Arx et al. 1988; BenSalah and Aalbu 1992; Salah et al. 1994; Laarif et al. 2003). Tubers stored for seed can be treated with pyrethroids and organophosphates in certain cases (Islam et al. 1990; Das et al. 1992; Hossain et al. 1994; Hanafi 1999; Keasar et al. 2005), although the practice can be illegal and life threatening when used inappropriately. Under rustic storage conditions in the Philippines, granulo-viruses $(\mathrm{GV})$ at $5 \mathrm{~kg} \cdot \operatorname{ton}^{-1}$ of tubers 
has been effective for up to 2 months of storage; treatment combinations of $\mathrm{GV}+\mathrm{Bt}+$ deltametrhin + Lantana or deltamehtrin $+\mathrm{Bt}+\mathrm{GV}$ yielded zero to low pest infestation; Bt alone was ineffective (Das et al. 1992). In India, stored tubers covered with dried and chopped leaves of Lantana reduced tuber damage from 99 to 5\%; likewise, Eucalyptus leaves reduced tuber damage to $8 \%$ (Lal 1988). In Peru, Eucalyptus globosus, Lantana camara, and Minthostachys, both in dried and powdered forms were effective in controlling $P$. operculella (Raman et al. 1987).

\section{Searching for Resistance}

Reducing $P$. operculella damage through cultivar selection appears possible. The evaluation of potato germplasm for resistance to potato tuberworm is valuable to developing integrated tuberworm management (Horgan et al. 2007); however, no fully recognized resistance cultivar has been bred to date. Few attempts have been made to identify plant cultivars resistant to tuberworm (Foot 1976a; Raman and Palacios 1982; Musmeci et al. 1997; Arnone et al. 1998; Musmeci et al. 2005). In the late 70's, 20 cultivars were compared for foliar and tuber resistance with negative results (Foot 1976a). In the 80's, the International Potato Center tested 3,747 and 452 germplasm of primitive and wild potato species, respectively, from which 22 primitive and 21 wild germplasm were found resistant (Raman and Palacios 1982). In 2009, 13 germplasm were used for tuber resistance studies (Rondon et al. 2009). These germplasm were: A0008TE, A97066LB, NY123, PA00N10-5, PA99N2, PA99N82, Paciencia, Q174-2, Russet Burbank, Rubi, Ranger Russet, Spunta G2 (Cry1IA1= Cry5), and T88-4. Tuber resistance of potato germplasm was determined based on the number of mines per tuber and the number of live larvae. Tubers of the transgenic clone Spunta G2 (Douches et al. 2002) were resistant to tuberworm damage. All other germplasm tested in this study, including Russet Burbank and Ranger Russet, were susceptible to tuberworm in the field and laboratory experiments. Other host resistance studies have shown that there are independent resistance mechanisms in the foliage and tubers (Brown 2006). Malakar and Tingey (1999) found limited foliage resistance of Solanum berthaultii (Hawkes) to P. operculella, while Musmeci et al. (1997) found some foliar resistance on wild potatoes and interspecific hybrids. Little information is known regarding the effect of either leaf or tuber resistance on the biology and ecology of potato tuberworm (Malakar and Tingey 1999). A combination of partially resistant germplasm to $P$. operculella and appropriate management practices could answer the "zero" tolerance required by the potato industry (Rondon et al. 2009).

\section{Conclusions}

The potato crop is one of the world's most important food crops, along with rice, wheat, and maize (Ross 1986; Douches et al. 2004). Potatoes are widely grown over many latitudes and elevations. Especially in developing countries, potato production is important for subsistence and for adding nutritional balance (Douches et al. 2004; Navarre et al. 2009). Unfortunately, severe losses can occur in storage, especially in developing countries where low income farmers cannot afford refrigerated storages. Increasing potato production in a sustainable manner while protecting producers, consumers, and the environment requires an integrated approach. Combating pests such as $P$. operculella, a devastating worldwide pest of potatoes, is a continuous challenge that growers must face as they intensify their production techniques to satisfy the increasing demands of the international market.

Acknowledgments The author gratefully acknowledges Drs. Aymeric Goyer, Arnold Appleby, George H. Clough and Paul C. Jepson for their editorial comments. Thanks to Amanda Smith and Dustin Keys for gathering some of the information.

Open Access This article is distributed under the terms of the Creative Commons Attribution Noncommercial License which permits any noncommercial use, distribution, and reproduction in any medium, provided the original author(s) and source are credited.

\section{References}

Al-Ali, A.S., I.K. Al-Neamy, and S.A. Abbas. 1975. Observations on the biology of the potato tuber moth Phthorimaea operculella (Zeller) (Lepidoptera: Gelechiidae) in Iraq. Zeitschrift fuÉr Angewandte Entomologie 79: 345-351.

Alcázar, J., M. Cervantes, and K.V. Raman. 1992. Caracterización y patogenicidad de un virus granulosis de la polilla de la papa Phthorimaea operculella. Rev. per. Entomol. 35: 107-111.

Allen, H.W., and M.H. Brunson. 1947. Control of Nosema disease of potato tuberworm, a host used in the mass production of Macrocentrus ancylivorus. Sci. 394.

Amonkar, S.V., A.K. Pal, L. Vijayalakshmi, and A.S. Rao. 1979. Microbial control of potato tuber moth (Phthorimaea operculella Zell.). Indian Journal of Experimental Biology 17: 11271133.

Annecke, D.P., and M.J. Mynhardt. 1974. On the identity of Copidosoma koehleri Blanchard (Hymenoptera: Encrytidae). Journal of the Entomological Society of South Africa 37: 31-33.

Arnone, S., S. Musmeci, L. Bacchetta, N. Cordischi, E. Pucci, M. Cristofaro, and A. Sonino. 1998. Research in Solanum spp. as sources of resistance to the potato tuber moth Phthorimaea operculella (Zeller). Potato Research 41: 39-49.

Arthurs, S.P., L.A. Lacey, and F. de la Rosa. 2008. Evaluation of a granulovirus (PoGV) and Bacillus thuringiensis subsp kurstaki for control of the potato tuberworm (Lepidoptera: Gelechiidae) in stored tubers. Journal of Economic Entomology 101: 1540-1546.

Ascerno, M. 1991. Insect phenology and integrated pest management. Journal of Arboriculture 17: 13-15. 
Attia, R., and B. Mattar. 1939. Some notes on the potato tubermoth Phthorimaea operculella Zell. Bull. Soc. Entomol. Egypt 216: 136

Awate, B.G., and L.M. Naik. 1979. Efficacies of insecticidal dusts applied to soil surface for controlling potato tuberworm (Phthorimaea operculella Zeller) in field. Journal of Maharashtra Agricultural Universities 4: 100.

Bacon, O.G. 1960a. Systemic insecticides applied to cut seed pieces and to soil at planting time to control potato insects. Journal of Economic Entomology 53: 835-839.

Bacon, O.G. 1960b. Control of the potato tuberworm in potatoes. Journal of Economic Entomology 53: 868-871.

Bacon, O.G., N.F. McCalley, W.D. Riley, and R.H. James. 1971. Evaluation of insecticides for control of the green aphid and potato tuberworm on Irish potatoes. American Potato Journal 48: 298.

Bacon, O.G., N.F. McAlley, W.D. Riley, and R.H. James. 1972. Insecticides for control of potato tuber worm and green peach aphid on potatoes in California. American Potato Journal 49: 291-5.

Bacon, O.G., J.N. Seiber, and G.G. Kennedy. 1976. Evaluation of survey trapping techniques for potato tuberworm moths (Phthorimaea operculella) with chemical baited traps. Journal of Economic Entomology 69: 569-572.

Balachowsky, A.S., and P. Real. 1966. La teigne de la pomme de terre. In A.S. Balachoswky (ed.) Entomologie appliquee a l'agriculture, Tome II, Lepidopteres, Vol. i. : 371-381.

Barragan, A.R. 2005. Identificación, biologia, y comportamiento de las polillas de la papa en el Ecuador, 1-11. Ecuador: PROMSAMAG, PUCE.

Bartoloni, P. 1951. La Phthorimaea operculella Zeller (Lep. Gelechiidae) in Italia. Redia 36: 301-379.

Beegle, C.C., and T. Yamamoto. 1992. History of Bacillus thuringensis Berliner research and development. Canadian Entomologist 124: 587-616.

BenSalah, H., and R. Aalbu. 1992. Field use of granulosis virus to reduce initial storage infestation of the potato tuber moth, Phthorimaea operculella (Zeller), in North Africa. Agriculture, Ecosystems \& Environment 38: 119-126.

Berlinger, M.J. 1992. Pests of processing tomatoes in Israel and suggested IPM model. Act. Hort. 301: 185-192.

Berthon, C.H. 1855. On the potato moth. Proceedings of the Royal Society of Van Diemen's Land 3: 76-80.

Briese, D.T. 1981. The incidence of parasitism and disease in field populations of the potato moth Phthorimaea operculella (Zeller) in Australia biological control. Journal of the Australian Entomological Society 20: 319-326.

Briese, D.T. 1986. Geographic variability in demographic performance of the potato moth, Phthorimaea operculella Zell. in Australia. Bulletin of Entomological Research 76: 719-726.

Briese, D.T., and H.A. Mende. 1981. Differences in susceptibility to a granulosis virus field populations of the potato moth, Phthorimaea operculella (Zeller) (Lepidoptera: Gelechiidae). Bulletin of Entomological Research 71: 11-18.

Briese, D.T., and H.A. Mende. 1983. Selection for increased resistance to a granulosis virus in the potato moth, Phthorimaea operculella (Zeller) (Lepidoptera: Gelechiidae) viral insecticides, biological control. Bulletin of Entomological Research 73: 1-9.

Brits, J.A. 1979. The influence of age on the adult male reproductive system of the potato tuber moth, Phthorimaea operculella Zell. Journal of the Entomological Society of Southern Africa 42: 395-400.

Broodryk, S.W. 1970. Dimensions and developmental values for potato tuber moth Phthorimaea operculella (Zeller) in South Africa. Phytophylactica 2: 215-216.

Broodryk, S.W. 1971. Ecological investigations on the potato tuber moth, Phthorimaea operculella (Zeller) (Lepidoptera: Gelechiidae). Phytophylactica 3: 73-84.
Broodryk, S.W., and L.M. Pretorius. 1974. Occurrence in South Africa of a granulosis virus attacking potato tuber moth, Phthorimaea operculella (Zeller) (Lepidoptera: Gelechiidae). Journal of the Entomological Society of Southern Africa 37: $125-128$.

Brown, C. 2006. Breeding for resistance to tuber moth, powdery scab, black dot, and nematode cause problems. Pasco, WA: Washington State Potato Commision progress reports.

Broza, M., and B. Sneh. 1994. Bacillus thuringiensis ssp. kurstaki as an effective control agent of Lepidopteran pests in tomato fields in Israel. Journal of Economic Entomology 87: 923-928.

Callan, E.M. 1974. Changing status of the parasites of potato tuber moth Phthorimaea operculella (Lepidoptera: Gelechiidae) in Australia. Entomophaga 19: 97-101.

Cameron, P.J., G.P. Walker, G.M. Penny, and P.J. Wingley. 2002. Movement of potato tuberworm (Lepidoptera: Gelechiidae) within and between crops, and some comparisions with diamonback moth (Lepidoptera: Pluteliidae). Environmental Entomology 31: 65-75.

Cannon, R.C. 1948. Investigations in the control of the potato tuber moth, Gnorimoschema operculella Zell. (Lepidoptera: Gelechiidae) in north Queensland. Queesnland Journal of Agricultural Sciences 5: $107-124$.

Cardona, C., and E.R. Oatman. 1975. Biology and the physical ecology of Apanteles subandinus Blanchard (Hymenoptera: Braconidae), with notes on temperature responses of Apanteles scutellaris Muesbeck and its host, the potato tuber worm (Phthorimaea opeculella), biological control. Hilgardia 43: 1-51.

Chauhan, U., and L.R. Verma. 1985. Adult eclosion and mating behaviour of potato tubermoth, Phthorimaea operculella Zeller. Journal of the Indian Potato Association 12: 148-157.

Chauhan, U., and L.R. Verma. 1991. Biology of potato tuber moth Phthorimaea operculella Zeller with special reference to pupal eye pigmentation and adult sexual dimorphism. Journal of Economic Entomology 16: 63-67.

Chi, H., and W.M. Getz. 1988. Mass rearing and harvesting based on an age-stage, two-sex life table: a potato tuberworm (Lepidoptera: Gelechiidae) case study. Environmental Entomology 17: 18-25.

Chittenden, F.H. 1912. The potato tuber moth (Phthorimaea operculella Zeller). United State Department of Agriculture 162: 5.

Chittenden, F.H. 1913. The potato tubermoth. United States Department of Agriculture Farmer's Bulletin: 1-7.

Choe, K.R., C.G. Yoo, and Y.D. Chang. 1980. Studies on the life history of potato tubermoth, Phthorimaea operculella Zeller. Korean Journal of Plant Protection 9: 97-100.

Chundurwar, R.D. 1977. Density dependent response of potato tuber moth parasite, Orgilus parcus (Hymenoptera: Braconidae). Journal of Maharashtra Agricultural Universities 2: 248-252.

Chundurwar, R.D. 1978. Biology of Agathis unicolorata Shenefelt, a larval parasite of Phthorimaea operculella Zeller. Journal of Maharashtra Agricultural Universities 3: 44-46.

Clough, G., S. DeBano, S. Rondon, N. David, and P. Hamm. 2008. Use of cultural and chemical practices to reduce tuber damage from the potato tuberworm in the Columbia Basin. Hortscience 43: $1159-1160$

Coll, M., S. Gavish, and I. Dori. 2000. Population biology of the potato tubermoth, Phthorimaea opercuella (Lepidoptera: Gelechiidae) in two potato cropping systems in Israel. Bulletin of Entomological Research 90: 309-315.

Cory, F.M. 1925. The potato tuber moth. University of Maryland Extension Service 57: 3.

Cruickshank, S., and F. Ahmed. 1973. Biological control of potato tuber moth, Phthorimaea operculella (Zell.) (Lepidoptera: Gelechiidae) in Zambia. Commonw. Inst. Biol. Control. Tech. Bull 16: 62.

Cunningham, I.C. 1969. Alternative host plants of tobacco leaf-miner (Phthorimaea operculella (Zell.)). Queensland Journal of Agricultural \& Animal Sciences 26: 107-111. 
Das, G.P., and K.V. Raman. 1994. Alternate hosts of the potato tuber moth, Phthorimaea operculella (Zeller). Crop Protection 13: 83-86.

Das, G.P., E.D. Magallona, and K.V. Raman. 1992. Effects of different components of IPM in the management of the potato tuber moth, in storage. Agriculture, Ecosystems \& Environment 41: 321-325.

Davoud, M.A., G.B. El-Saadany, F.M.A. Mariy, and M.Y. Ibrahim. 1999. The thermal threshold units for Phthorimaea operculella (Zeller). Annals of Agricultural Science, Ain-Shams University, Cairo 44: 379-393.

DeBano, S.J., P.B. Hamm, A. Jensen, S.I. Rondon, and P.J. Landolt. 2010. Spatial and temporal dynamics of potato tuberworm (Lepidoptera: Gelechiidae) in the Columbia Basin of the Pacific Northwest. Journal of Economic Entomology (Accepted).

Divakar, B.J., and A.D. Pawar. 1979. Field recovery of Chelonus blackburni and Bracon hebator from potato tubermoth. Indian Journal of Plant Protection 7: 214.

Dŏgramaci, M., S.I. Rondon, and S.J. DeBano. 2008. The effect of soil depth and exposure to winter conditions on survival of the potato tuberworm Phthorimaea operculella (Lepidoptera: Gelechiidae). Entomologia Experimentalis et Applicata 129: 332 339.

Doreste, S.E., and M. Nieves. 1968. Estudios de laboratorio sobre el ciclo biologico del minador de la hoja del tabaco, papa y tomate, Gnorimoschema operculella (Zeller). Agronomie Tropicale 18: 461-474.

Douches, D.S., W. Li, K. Zarka, J. Coombs, W. Pett, E. Grafius, and T. El-Nasr. 2002. Development of Bt-cry5 insect-resistant potato lines 'Spunta-G2' and 'Spunta-G3'. HortScience 37: 1103-1107.

Douches, D.S., W. Pett, F. Santos, J. Coombs, E. Grafius, E.A.W.L. Metry, T.N. El-Din, and M. Madkour. 2004. Field and storage testing Bt potatoes for resistance to potato tuberworm (Lepidoptera: Gelechiidae). Journal of Economic Entomology 97: 1425-1431.

Doutt, R.L. 1947. Polyembryony in Copidosoma koehleri Blanchard. American Naturalist 81: 435-453.

Elbadry, E. 1964. Suppression of the reproductive potential of the potato tuberworm, Gnorimoschema operculella by gamma irradiation. Journal of Economic Entomology 57: 414-415.

El-Sherif, A.R.A. 1961. Preliminary biological studies on the potato tuber worm in UAR. Gnorimoschema operculella (Zeller) (Lepidoptera: Tineidae). Agricultural Research Review Cairo 39: 288-298.

Essamet, M., R. von Arx, P.T. Ewell, J. Goueder, A. Ben Temine, and M. Cheikh. 1988. Aspects tehcniques et economiques du problem del a teigne et du stokage des pommes de terre de saison en Tunisie. Ann. Inst. Nat. Rech. Agron. Tunis. 61: 1-50.

Etzel, L. K. 1985. Phthorimaea operculella. In Singh, P., and Moore, R.F. (eds.). Handbook of insect rearing. Vol. II: 431-442.

Fadli, H.A., G.A.W. Al-Salih, and A.E. Abdul-Masih. 1974. A survey of the potato tuber moth in Iraq. Journal in Iraqi Agriculture 29: 35-37.

Farrag, R.M. 1998. Control of the potato tuber moth, Phthorimaea operculella Zeller (Lepidoptera Gelechiidae) at storage. Egyptian Journal of Agricultural Research 76: 947-952.

Fenemore, P.G. 1977. Oviposition of potato tuber moth, Phthorimaea operculella Zell., fecundity in relation to mated state, age, and pupal weight. New Zealand Journal of Zoology 4: 187-191.

Fenemore, P.G. 1978. Oviposition of potato tuber moth, Phthorimaea operculella Zell. (Lepidoptera: Gelechiidae); the physical nature of the oviposition substrate. New Zealand Journal of Zoology 5: 591-599.

Fenemore, P.G. 1979. Oviposition of potato tuber moth, Phthorimaea operculella Zell. (Lepidoptera: Gelechiidae); the influence of adult food, pupal weight, and host-plant tissue on fecundity. New Zealand Journal of Zoology 7: 389-395.

Fenemore, P.G. 1988. Host-plant location and selection by adult potato moth, Phthorimaea operculella (Lepidoptera: Gelechiidae): a review. Journal of Insect Physiology 34: 175-177.
Finney, G.L. 1947. Mass culture of Macrocentrus ancylivorus and its host, the potato tuber moth. Hilgardia 17: 437-483.

Finney, G.L., S.E. Flanders, and H.S. Smith. 1944. The potato tuber moth as a host for mass production of Macrocentrus ancylivorus. Journal of Economic Entomology 38: 61-64.

Flanders, S.E. 1930. Mass production of egg parasites of the genus Trichogramma. Hilgardia 4: 465-501.

Flanders, S.E. 1935. Host influence on the prolificacy and size of Trichogramma. Pan. Pac. Entomol. 11: 175-177.

Flanders, S.E. 1945. Mass production of Trichogramma using eggs of potato tuber worm. Journal of Economic Entomology 38: 394-395.

Flanders, R.V., and E.R. Oatman. 1982. Laboratory studies on the biology of Orgilus-jenniae (Hymenoptera, Braconidae), a parasitoid of the potato tuberworm, Phthorimaea operculella (Lepidoptera: Gelechiidae). Hilgardia 50: 1-33.

Flanders, R.V., and E.R. Oatman. 1987. Competitive interactions among endophagous parasitoids of potato tuberworm larvae in southern-California. Hilgardia 55: 1-34.

Fletcher, T.B. 1914. Some south Indian insects and other animals of importance considered especially from an economic point of view. Madras: Government Press: 23:563.

Flint, M. 1986. Integrated pest management for potatoes in the Western United States. Pub. 3316. Univ. of Cal: 1-146.

Foley, D.H. 1985. Tethered flight of the potato moth, Phthorimaea operculella. Physiological Entomology 10: 45-51.

Foot, M.A. 1974a. Field assessment of several insecticides against the potato tuber moth Phthorimaea operculella (Zell.) at Pukukohe. New Zealand Journal of Experimental Agriculture 2: 191-197.

Foot, M.A. 1974b. Cultural practices in relation to infestation of potato crops by the potato tuber moth (Phthorimaea operculella). I. Effect of irrigation and ridge width. New Zealand Journal of Experimental Agriculture 2: 447-450.

Foot, M.A. 1976a. Susceptibility of twenty potato cultivars to the potato moth (Phthorimaea operculella) at Pukekohe: A preliminary assessment. New Zealand Journal of Experimental Agriculture 4: 239-242.

Foot, M.A. 1976b. Cultural practices in relation to infestation of potato crops by the potato tuber moth (Phthorimaea operculella). II. Effect of seed depth, re-moulding, pre-harvest defoliation, and delayed harvest. New Zealand Journal of Experimental Agriculture 4: 121-124.

Foot, M.A. 1976c. Laboratory assessment of several insecticides against the potato tuber moth (Phthorimaea operculella Zeller). 19: $117-125$.

Foot, M.A. 1979. Bionomics of the potato tuber moth, Phthorimaea operculella (Lepidoptera: Gelechiidae) at Pukekohe. New Zealand Journal of Zoology 6: 623-636.

Franzman, B.A. 1980. Parasitism of Phthorimaea operculella (Lepidoptera: Gelechiidae) larvae in Queensland. Entomophaga 25: 369-372.

French, J.G. 1915. The potato moth. Phthorimaea operculella Zeller Recent spraying experiments in Gippsland. Journal in Department Agriculture of Victoria 23: 6144-6180.

Gilboa, S., and H. Podoler. 1995. Presence-absence sequentials sampling for potato tuberworm (Lepidoptera: Gelechiidae) on processing tomatoes: selection of sample sites according to predictable seasonal trends. Journal of Economic Entomology 88: 1332-1336.

Graft, J.E. 1917. The potato tubermoth. Tech. Bull. USDA 427: 58.

Gubbaiah, and T.S. Thontadarya. 1975. Chemical control of the tuber worm. Gnorimoschema operculella Zell. in Karnataka. Mysore Journal of Agricultural Sciences 9: 415-417.

Gubbaiah, and T.S. Thontadarya. 1977. Bionomics of Potato Tuberworm, Gnorimoschema-Operculella Zeller (Lepidoptera Gelechiidae) in Karnataka. Mysore Journal of Agricultural Sciences 11: 380-386.

Hafez, M., F.N. Zaki, A. Moursy, and M. Sabbour. 1997. Biological effects of the entomopathogenic fungus, Beauveria bassiana on 
the potato tuber moth Phthorimaea operculella (Zeller). Anz. Schadl. Pflanz. Umwelt. 70: 158-159.

Haines, C.P. 1977. The potato tuber moth, Phthorimaea operculella (Zeller): a bibliography of recent literature and a review of its biology and control on potatoes in the field and in store. Rep. Tropical Products Institute G112, 3: 15.

Hamilton, J.T., and J.A. Macdonald. 1990. Control of potato moth, Phthorimaea operculella (Zeller) in stored seed potatoes. General and Applied Entomology 22: 3-6.

Hanafi, A. 1999. Integrated pest management of potato tuber moth in field and storage. Potato Research 42: 373-380.

Harpaz, I., and M. Wysoki. 1984. Susceptibility of the carob moth, Ectomyelois ceratoniae to Bacillus thuringensis. Phytoparasitica 12: $189-191$.

Herman, T.J.B., J.R. Clearwater, and C.M. Triggs. 2005. Impact of pheromone trap design, placement and pheromone blend on catch of potato tuber moth. New Zealand Plant Protection $219-223$

Hofmaster, R.N. 1959. Effectiveness of new insecticides on the potato leaf-hopper and the influence of leafhopper control and potato variety on tuberworm infestations. Journal of Economic Entomology 52: 908-910.

Hofmaster, R.N., and R.L. Waterfield. 1972. Insecticide control of the potato tuberworm in late-crop potato foliage. American Journal of Potato Research 49: 383-90.

Horgan, F.G., D.T. Quiring, A. Lagnaoui, A. Salas, and Y. Pelletier. 2007. Mechanism of resistance to tuber-feeding Phthorimaea operculella (Zeller) in two wild potato species. Entomologia Experimentalis et Applicata 125: 249-258.

Horne, P.A. 1990. The influence of introduced parasitoids on the potato moth, Phthorimaea operculella (Lepidoptera: Gelechiidae) in Victoria, Australia. Bulletin of Entomological Research 80: 159163.

Horne, P.A. 1993. Sampling for the potato moth (Phthorimaea operculella) and its parasitoids. Australian Journal of Experimental Agriculture 33: 91-96.

Hossain, S.M.Z., G.P. Das, and M.Z. Alam. 1994. Use of various indigenous materials and insecticides in controlling potato tuber moth in storage. Bulletin of the Institute of Tropical Agriculture Kyushu University 17: 79-84.

Hunter, D.K. 1973. Viruses of stored-product insects and their potential as control agents. Miscellaneous Publications of the Entomological Society of America 9: 62-65.

Hunter, D.K., D.F. Hoffmann, and S.J. Collier. 1975. Observations on a granulosis virus of potato tuberworm, Phthorimaea operculella. Journal of Invertebrate Pathology 26: 397-400.

Ilangantileke, S.G., V.S. Khatana, J.P. Singh, and D. Kumar. 1997. Improved rustic storage in South Asia. CIP Publications, 1995-6 program 6: postharvest management, marketing, Lima-Peru.

Islam, M.N., M.A. Karim, and Z. Nessa. 1990. Control of the potato tuber moth, Phthorimaea operculella (Zeller) (Lepidoptera: Gelechiidae) in the storehouses for seed and ware potatoes in Bangladesh. Bangladesh Journal of Zoology 18: 41-52.

Izhevskiy, S.S. 1985. Review of the parasites of the potato tuber moth Phthorimaea operculella Zell. (Lepidoptera: Gelechiidae). Entomological Review 64: 148-160.

Jai Rao, K. 1967. Trials with the Taiwan strain of Lixophaga diatraeae Tns. in India. Technical Bulletin of the Commonwealth Institute of Biological Control 9: 25-29.

Jensen, A., P. Hamm, A. Schreiber, and S. DeBano. 2005. Prepare for tuber moth in 2005. Potato Progress 5: 1-4.

Keasar, T., A. Kalish, O. Becher, and S. Steinberg. 2005. Spatial and temporal dynamics of potato tuberworm (Lepidoptera: Gelechiidae) infestation in field-stored. Journal of Economic Entomology 98: $222-228$
Keller, S. 2003. Integrated pest management of the potato tuber moth in cropping systems of different agro-ecological zones. In Advances in Crop Research ed. J. Kroschel, 153 Margraft Verlag.

Kennedy, G.G. 1975. Trap design and other factors influencing capture of male potato tuberworm (Lepidoptera: Gelechiidae) moths by virgin female baited traps. Journal of Economic Entomology 68: 305-308.

Kfir, R. 1981a. Fertility of the polyembryonic parasite Copidosoma koehleri, effect of humidities on life length and relative abundance as compared with that of Apanteles subandinus in potato tuber moth Phthorimaea operculella, biological control. Annals of Applied Biology 99: 225-230.

Kfir, R. 1981b. Effect of hosts and parasite density on the egg parasite Trichogramma pretiosum (Hymenoptera: Trichogrammatidae) Biological control of Heliothis armigera, Phthorimaea operculella and Sitotroga cereallela, South Africa. Entomophaga 26: 445-451.

Kfir, R. 1983. Functional response to host density by the egg parasite Trichogramma pretiosum. Entomophaga 28: 345-353.

Klomp, H., and B.J. Teerink. 1962. Host selection and number of eggs per oviposition in the egg parasite Trichogramma embryiphagum. Nature 195: 1020-1021.

Knipling, E.F. 1955. Possibilitites of insect control or erradication through the use of sexually sterile males. Journal of Economic Entomology 48: 459-462.

Koizumi, K. 1955. Effect of constant temperature upon the development of the potato tuber moth, G. operculella (Zeller). Science reports of the Faculty of Agriculture Okayama Univ 7: 36-45.

Koss, A. 2003. Integrating chemical and biological control in Washington State potato fields. Pullman: Washington State University. M.S. Thesis.

Krambias, A. 1976. Climactic factors affecting the catches of potato tuberworm, Phthorimaea operculella (Zeller) at a pheromone trap. Bulletin of Entomological Research 66: 81-85.

Kroschel, J. 1995. Integrated pest management in potato production in Yemen with special reference to the integrated biological control of the potato tuber moth (Phthorimaea operculella Zeller). Tropical Agriculture, 8. Weikersheim, Germany: Margraf Verlag.

Kroschel, J., and W. Koch. 1994. Studies on the population dynamics of the potato tuber moth Phthorimaea operculella Zeller (Lepidoptera: Gelechiidae) in the Republic of Yemen. Journal of Applied Entomology 118: 327-341.

Kroschel, J., and W. Koch. 1996. Studies on the use of chemicals, botanicals and Bacillus thuringiensis in the management of the potato tuber moth in potato stores. Crop Protection 15: 197-203.

Kroschel, J., H.J. Kaack, and E. Fritsch. 1996a. Biological control of the potato tuber moth (Phthorimaea operculella Zeller) in the Republic of Yemen using granulosis virus: propagation and effectiveness of the virus in field trials. Biocontrol Science and Technology 6: 217-226.

Kroschel, J., E. Fritsch, and J. Huber. 1996b. Biological control of the potato tuber moth (Phthorimaea operculella Zeller) in the Republic of Yemen using granulosis virus: biochemical characterization, pathogenicity and stability of the virus. Biocontrol Science and Technology 6: 207-216.

Laarif, A., S. Fattouch, W. Essid, N. Marzouki, H.B. Salah, and M.H. B. Hammouda. 2003. Epidemiological survey of Phthorimaea operculella granulosis virus in Tunisia. Bulletin OEPP 33: 335338.

Labeyrie, V. 1957. Influence de l'alimentation sur la ponte de la teigne de la pomme de terre (Gnorimoschema operculella Z.) (Lep. Gelechiidae). Bulletin of Social Entomology France 62: 64-67.

Labeyrie, V. 1959. Technique d'elevage de Chelonus contratus Nees, parasite de Phthorimaea ocellatella Boyd. Entomophaga 4: 4347. 
Lacey, L.A., and S.P. Arthurs. 2005. Microbial control of the potato tuber moth (Lepidoptera: Gelechiidae). Yakima Ag. Res. Lab. Report: 1-13.

Lacey, L.A., R. Frutos, H.K. Kaya, and P. Vail. 2001. Insects pathogens as biological control agents: Do they have a future? Biological Control 21: 230-248.

Lal, L. 1988. Potato tuber moth, Phthorimaea operculella (Zeller), in north eastern hills region and a simple method for its control. Indian Journal of Agricultural Science 58: 130-132.

Lall, B.S. 1949. Preliminary observations on the bionomics of potato tuber-moth (Gnorimoschema opercullela Zell.) and its control in Bihar, India. Indian Journal of Agricultural Science 19: 295-306.

Lall, L. 1989. Relationships between pheromone catches of adult moths, foliar larval populations and plant infestations by potato tuberworm in the field. Tropical Pest Management 35: 157-159.

Langford, G.S. 1932. Winter survival of the potato tuber moth Phthorimaea operculella Zell. Journal of Economic Entomology 25: 210-213.

Langford, G.S. 1933. Observations on cultural practices for the control of the potato tuberworm, Phthorimaea operculella (Zell.). Journal of Economic Entomology 26: 135-7.

Langford, G.S. 1934. Winter survival of the potato tuber moth, Phthorimaea operculella Zeller. Journal of Economic Entomology 27: $210-213$.

Langford, G.S., and E.N. Cory. 1932. Observations on the potato tuber moth. Journal of Economic Entomology 25: 625-34.

Langford, G.S., and E.N. Cory. 1934. Winter survival of the potato tuber moth, Phthorimaea operculella (Zeller). Journal of Economic Entomology 27: 210-213.

Lefroy, H.M. 1907. The potato tuber moth. Indian Agricultural Journal 2: 294-295.

Legg, D.E., S.M. Van Vleet, and J.E. Lloyd. 2000. Simulated predictions of insect phenological events made by using mean and median functional lower developmental thresholds. Journal of Economic Entomology 93: 658-661.

Leong, J.K.L., and E.R. Oatman. 1968. The biology of Campoplex haywardi (Hymenoptera: Ichneumonidae), a primary parasite of the potato tuberworm. Annals of the Entomological Society of America 61: 26-36.

Lery, X., J. Giannotti, and A. Taha. 1997. Multiplication of a granulosis virus isolated from the potato tuber moth in a new established cell line of Phthorimaea operculella. In Vitro Cellular and Developmental Biology 33: 640-646.

Lewis, W.J., D.A. Nordlund, H.R. Gross, W.D. Perkins, E.F. Knipling, and J. Voegele. 1976. Production and performance of Trichogramma reared on eggs of Heliothis zea and other hosts. Environmental Entomology 5: 449-452.

Lloyd, D.C. 1972. Some South American parasites of the potato tuber moth, Phthorimaea operculella (Zeller) and remarks on those in other continents. Commonw. Inst. Biol. Control. Tech. Bull. 15: $35-49$.

Lloyd, D.C., and A.S. Guido. 1963. Parasites of the potato tuber moth, Gnorrimoschema operculella. Commonw. Inst. Biol. Control. Tech. Bull. 3: 34.

Makee, H., and G. Saour. 1997. Inherited effects of F1 progeny of partially sterile male Phthorimaea operculella (Lepidoptera: Gelechiidae). Journal of Economic Entomology 90: 1097-1101.

Makee, H., and G. Saour. 1999. Nonrecovery of fertility in partially sterile male Phthorimaea operculella (Lepidoptera: Gelechiidae). Journal of Economic Entomology 92: 516-520.

Makee, H., and G. Saour. 2001. Factors influencing mating success, mating frequency, and fecundity in Phthorimaea operculella (Lepidoptera: Gelechiidae). Environmental Entomology 30: 31-36.

Malakar, R., and W.M. Tingey. 1999. Resistance of Solanum berthaultii foliage to potato tuberworm (Lepidoptera: Gelechiidae). Journal of Economic Entomology 92(2): 497-502.
Manickavasagar, P. 1953. The potato tuber moth Gnorimoschema operculella (Zeller) (Lepidoptera: Gelechiidae). Tropical Agriculturist 109: 118-122.

Martson, N., and L.R. Eartle. 1973. Host influence on the bionomics of Trichiogramma minutum. Annals of the Entomological Society of America 66: 1155-1162.

Matthiessen, J.N., R.L. Christian, T.D.C. Grace, and B.K. Fishie. 1978. Large scale field propagation and the purification of the granulosis virus of the potato moth Phthorimaea operculella (Zeller) (Lepidoptera: Gelechiidae). Bulletin of Entomological Research 68: 3389-3391.

Medina, R.F., and S.I. Rondon. 2008. Population structure of the potato tuberworm Phthorimaea operculella Zeller (Lepidoptera: Gelechiidae) in the United States In 6th Annual Meeting of the Entomol. Soc. of Amer. Nov. 16-19. Reno, NV.

Meisner, J. 1969. Atraction and repelllence in the potato tuber moth, Gnorismoschema operculella Zeller: phagostimulants and antifeedants for the larvae: some of the factors to oviposition. $\mathrm{PhD}$ thesis, Jerusalem, Israel: The Hebrew Univ.

Meisner, J., K.R.S. Ascher, and D. Lavie. 1974. Factors influencing the attraction to the potato tuber moth, Gnorimoschema operculella Zeller. Journal of Applied Entomology 77: 179-189.

Mercier, J., and J.L. Smilanick. 2005. Control of green mold and sour rot of stored lemon by biofumigation with Muscodor albus. Biological Control 32: 401-407.

Meyrick, E. 1902. A new genus of Gelechiidae. Entomological Magazine 38: 103-104.

Mitchell, B.L. 1978. The biological control of potato tuber moth Phthorimaea operculella (Zeller) in Rhodesia. Rhodesia Agricultural journal 75: 55-58.

Moregan, A.C., and S.E. Crumb. 1914. The tobacco split worm. Bull. US Dep. Ag. 59: 7.

Morris, H.M. 1933. Potato tuber moth (Phthorimaea operculella, Zell.). Cyprus agricultural journal 28: 111-115.

Mukherjee, A.K. 1949. Life-history and bionomics of potato moth (Gnorimoschema operculella Zell.) at Allahabad (U.P.) together with some notes on the external morphology of the immature stages. Journal of the Zoological Society of India 1: 57-67.

Musmeci, S., R. Ciccoli, V. Di Gioia, A. Sonnino, and S. Arnone. 1997. Leaf effects of wild species of Solanum and interspecific hybrids on growth and behavior of the potato tuber moth, Phthorimaea operculella Zeller. Potato Research 40: 417-430.

Musmeci, S., P. Gambino, V. Innocenzi, S. Arnone, and A. Lai. 2005. Eliciting of resistance against potato tuber moth larvae in tubers of Solanum tuberosum (+) S. pinnatisectum hybrids. Proc. Meeting Physiol. Section EAPR Acta Hort.-ISHS: 135-141.

Navarre, D.A., A. Goyer, and R. Shakya. 2009. Nutritional value of potatoes: vitamin, phytonutrient and mineral content. In "Advances in potato chemistry and technology" Ed. Jaspreet Singh and Lovedeep Kaur. Elsevier Inc.(In press).

Nirula, K.K. 1960. Control of potato tuber-moth. Indian Potato Journal 2: 47-51.

Nirula, K.K., and R. Kumar. 1964. Control of potato tuber-moth in country stores. Indian Potato Journal 6: 30-33.

Oatman, E.R., and G.R. Platner. 1974. The biology of Temelucha sp., plantensis group (Hymenoptera: Ichneumonidae), a primary parasite of the potato tuber worm. Annals of the Entomological Society of America 67: 275-280.

Oatman, E.R., G.R. Platner, and P.D. Greany. 1969. The bilogy of Orgilus lepidus (Hymenoptera: Braconidae), a primary parasite of the potato tuberworm. Annals of the Entomological Society of America 62: 1407-1414.

Odebiyi, J.A., and E.R. Oatman. 1972. Biology of Agathis gibbosa (Hymenoptera.: Braconidae), a primary parasite of the potato tuber worm. Annals of the Entomological Society of America 65: $1104-1114$. 
Odebiyi, J.A., and E.R. Oatman. 1977. Biology of Agathis unicolor (Schrottky) and Agathis gibbosa (Say) (Hymenoptera: Braconidae), primary parasites of the potato tuberworm Phthorimaea operculella. Hilgardia 45: 123-151.

Ono, T., and T. Saito. 1973. Mating time and effects of the ligh condition on mating in potato tuber moth Phthorimaea operculella Zeller. Japanese Journal of Applied Entomology and Zoology 17: 127-131.

Ono, T., K. Tyatomi, and T. Saito. 1972. Mating behavior of the potato tuber moth. Phthorimaea operculella Zeller. Japanese Journal of Applied Entomology and Zoology 16: 51-53.

Persoons, C.J., S. Voerman, P.E.J. Verwiel, F.J. Ritter, W.J. Nooyen, and A.K. Minks. 1976. Sex-pheromone of potato tuberworm moth, Phthorimaea operculella - isolation, identification and field evaluation. Entomologia Experimentalis et Applicata 20: 289-300.

Platner, G.R., and E.R. Oatman. 1968. An improved technique for producing potato tuberworm eggs for production of natural enemies. International bibliography, information, documentation 61: 1054-1057.

Platner, G.R., and E.R. Oatman. 1972a. Techniques for culturing and mass producing parasites of the potato tuberworm. Journal of Economic Entomology 65: 1336-1338.

Platner, G.R., and E.R. Oatman. 1972b. Techniques for culturing and mass producing parasites of potato tuberworm (Lepidoptera: Gelechiidae). Journal of Economic Entomology 65: 1336.

Povolny, D. 1964. Gnorimoschemini trib. nov. eine neie Tribus der familie Gelechiidae nebst Bemerkungen zu ibrer taxonomic (Lepidoptera). Cassopis Ceskoslovenske Spolecnosti Entomologicke 61: 330-359.

Povolny, D., and L. Weismann. 1958. Kritischer Beitrag zur Problematik der Ruben Phthorimaea operculella (Zeller). Folia Zoologica 8: 97-121.

Powers, N.R., and E.R. Oatman. 1984. Biology and temperature responses of Chelonus kellieae and Chelonus-phthorimaeae (Hymenoptera: Braconidae) and their host, the potato tuberworm, Phthorimaea operculella (Lepidoptera: Gelechiidae). Hilgardia 52: 1-32.

Radcliffe, E.B. 1982. Insect pest of potato. Annual Review of Entomology 27: 173-204.

Raman, K.V. 1988. Control of potato tuber moth Phthorimaea operculella with sex pheromones in Peru. Agriculture, Ecosystems, and Environment 21: 85-99.

Raman, K.V. 1994. Pest management in developing countries. In Advances in Potato Pest Biology and Management, ed. G.W. Zehnder, M.L. Powelson, R.K. Jansson, and K.V. Raman, 583596. St. Paul: The American Phytopathological Society.

Raman, K.V., and M. Palacios. 1982. Screening potato for resistance to potato tuberworm. Journal of Economic Entomology 75: 4749.

Raman, K.V., R.H. Booth, and M. Palacios. 1987. Control of potato tuber moth Phthorimaea operculella (Zeller) in rustic potato stores. Tropical Science 27: 175-194.

Rao, J.K. 1967. Trials with the Taiwan strain of Lixophaga diatraeae Tns. in India. Tech. Bull. Commonw. Inst. Biol. Control 9: 25-29.

Rao, V.P., and K. Ramachandran-Nair. 1967. Occurrence of Bracon gelechiae Ashmead as a parasite of potato tuber moth, Gnorimoschema operculella (Zeller) in the field in Mysore State and Assam and its other hosts recorded in India. Tech. Bull. Commonw. Inst. Biol. Control 9: 73-75.

Rao, V.P., and H. Nagaraja. 1968. Morphological differences between Apanteles scutellaris Muesebeck and A. subandinus Blanchard, parasites of the potato tubermoth, Gnorimoschema operculella (Zeller). Tech. Bull. Commonw. Inst. Biol. Control 10: 57-65.

Redolfi, I., and G. Vargas. 1983. Apanteles gelechiidivoris Marsh (Hymenoptera: Braconidae) parasitoids of tubermoths (Lepidoptera: Gelechiidae) in Peru. Rev. Per. Entomol. 26: 5-7.
Reed, E.M. 1969. A granulosis virus of potato moth. Australian Journal of science 31: 300-301.

Reed, E.M. 1971. Factors affecting the status of a virus as a control agent for the potato moth (Phthorimaea operculella (Zell.) (Lepidoptera: Gelechiidae). Bulletin of entomological research 61: 207-222.

Reed, E.M., and B.P. Springett. 1971. Large-scale field testing of a granulosis virus for the control of the potato moth (Phthorimaea operculella (Zell.) (Lepidoptera: Gelechiidae). Bulletin of Entomological Research 61: 223-233.

Roelofs, W.L., J.P. Kochansky, R.T. Carde, G.G. Kennedy, C.A. Henrick, J.N. Labovitz, and V.L. Corbin. 1975. Sex-pheromone of potato tuberworm moth, Phthorimaea operculella. Life Sciences 17: 699-706.

Rondon, S.I. and L. Xue. 2010. Practical techniques and accuracy for sexing the potato tuberworm, Phthorimaea operculella (Lepidoptera: Gelechiidae). Fla. Entomol. (Accepted).

Rondon, S.I., S.J. DeBano, G.H. Clough, P.B. Hamm, A. Jensen, A. Schreiber, J.M. Alvarez, M. Thornton, J. Barbour, and M. Dŏgramaci. 2007. Biology and management of the potato tuberworm in the Pacific Northwest. PNW 594.

Rondon, S.I., S.J. DeBano, G.H. Clough, P.H. Hamm, and A. Jensen. 2008. Ocurrence of the potato tuber moth in the Columbia Basin of Oregon and Washington. In Integrated Pest Management for the Potato Tuber Moth, Phthorimaea operculella Zeller-a Potato Pest of Global Importance. Tropical Agriculture 20, Advances in Crop Research 10, ed. J. Kroschel and L. Lacey, 913. Weikersheim: Margraf.

Rondon, S.I., D. Hane, C.R. Brown, M.I. Vales, and M. Dŏgramaci. 2009. Resistance of potato germplasm to the potato tuberworm (Lepidoptera: Gelechiidae). Journal of Economic Entomology 102(4): 1649-1653.

Ross, H. 1986. Potato breeding and perspectives. Berlin: Verlag. 123.

Rothschild, G.H.L. 1986. The potato moth: an adaptable pest of short term cropping systems. In The ecology of exotic plants and animals, ed. R.L. Kitching, 144-162. Brisbane: Wiley.

Roux, O., and J. Baumgartner. 1998. Evaluation of mortality factors and risk analysis for the design of an integrated pest management system. Ecological Modelling 109: 61-75.

Roux, O., R. Vonarx, and J. Baumgartner. 1992. Estimating potato tuberworm (Lepidoptera: Gelechiidae) damage in stored potatoes in Tunisia. Journal of Economic Entomology 85: 2246-2250.

Salah, H.B., K. Fuglie, A.B. Temime, A. Rahmouni, and M. Cheikh. 1994. Utilisation du virus de la granulose de la teigne de la pomme de terre et du Bacillus thuringiensis dans la lutte integree contre Phthorimaea operculella Zell. (Lepid., Gelechiidae) en Tunisie. Ann. Inst. Nat. Recher. Agronom. Tunisie 67: 1-20.

Salama, H.S., N.Z. Dimetry, and A.M. Sharaby. 1972. Contributions to the biology of the potato tuber moth, Phthorimaea operculella Zell in Egypt (Lepidoptera: Gelechiidae). Bull. Soc. Entomol. Egypt. 56: 61-68.

Salama, H.S., M. Ragaei, and M. Sabbour. 1995a. Larvae of Phthorimaea operculella (Zell.) as affected by various strains of Bacillus thuringiensis. Journal of Applied Entomology 119: 241-243.

Salama, H.S., F.N. Zaki, M. Ragaei, and M. Sabbour. 1995b. Persistence and potency of Bacillus thuringiensis against Phthorimaea operculella (Zell.) (Lepidoptera: Gelechiidae) in potato stores. Journal of Applied Entomology 119: 493-494.

Salas, J., C. Alvarez, and A. Parra. 1991. Evaluacion de dos componentes de la feromona sexual, tres disenos y altura de colocacion de trampas en la eficiencia de atraccion y captura de adultos machos de Phthorimaea opercuella. Agron. Tropical 41: $169-178$.

Sankaran, T., and D.J. Girling. 1980. The current satus of biological control of the potato tuber moth. Biocontrol News and Information 1: 207-211. 
Santorini, A.P. 1971. Observations sur l'elevage en laboratoire de Phthorimaea operculella (Zeller) (Lepidoptera: Gelechiidae). Ann. de l'Institut Phytopathologique Benaki 10: 141-147.

Saour, G., and H. Makee. 1997. Radiation induced sterility in male potato tuber moth Phthorimaea operculella Zeller (Lepidoptera: Gelechiidae). Journal of Applied Entomology 121: 411-415.

Setiawati, W., R.E. Soeriaatmadja, T. Rubiati, and E. Chujoy. 1999. Control of potato tubermoth (Phthorimaea operculella) using an indigenous granulosis virus in Indonesia. Indonesian J. Crop Sci. 14: $10-16$

Sewify, G.H., S. Abol-Ela, and M.S. Eldin. 2000. Effects of the entomopathogenic fungus Metarhizium anisopliae (Metsch.) and granulosis virus $(\mathrm{GV})$ combinations on the potato tuber moth Phthorimaea operculella (Zeller) (Lepidoptera: Gelechiidae). Bull. Faculty Agric., Univ. Cairo 51: 95-106.

Shands, W.A., N. Allen, and J.W. Gilmore. 1938. A survey of insect injury to tobacco grow for the flue curing. Journal of Economic Entomology 3: 116-117.

Shelton, A.M., and J.A. Wyman. 1979a. Time of tuber infestation and relationships between catches of adult moths, foliar larval populations, and tuber damage by potato tuber worm. Journal of Economic Entomology 72: 599-601.

Shelton, A.M., and J.A. Wyman. 1979b. Potato tuberworm damage to potato grown under different irrigation and cultural practices. Journal of Economic Entomology 72: 261-264.

Shelton, A.M., and J.A. Wyman. 1980. Post-harvest potato tuberworm Lepidoptera, Gelechiidae population-levels in cull and volunteer potatoes, and means for control. Journal of Economic Entomology 73: 8-11.

Shorey, H.H., A.S. Deal, R.L. Hale, and M.J. Snyder. 1967. Control of potato tuberworms with Phosphamidon in southern California. International bibliography, information, documentation 60: 892893.

Sporleder, M. 2003. The granulovirus of the potato tuber moth Phthorimaea operculella (Zeller): Characterization and prospects for effective mass production and pest control. In Advances in Crop Research, ed. J. Kroschel, 206. Weikersheim: Verlag.

Sporleder, M., O. Zegarra, J. Kroschel, J. Huber, and A. Lagnaoui. 2001. Assessment of the inactivation time of Phthorimaea operculella granulovirus (PoGV) at different intensities of natural irradiation. Scientist-and-farmer:-partners-in-researchfor-the-21st-Century-Program-Report-1999-2000, 123-128. Lima: Centro Internacional de la Papa.

Sporleder, M., J. Kroschel, M.R.G. Quispe, and A. Lagnaoui. 2004. A temperature-based simulation model for the potato tuberworm, Phthorimaea operculella Zeller (Lepidoptera: Gelechiidae). Environmental Entomology 33: 477-486.

Sporleder, M., J. Kroschel, J. Huber, and A. Lagnaoui. 2005. An improved method to determine the biological activity (LC50) of the granulovirus PoGV in its host Phthorimaea operculella. Entomol. Exp. Appl. 116: 191-197.

Sporleder, M., R. Simon, H. Juarez, and J. Kroschel. 2008. Regional and seasonal forecasting of the potato tuber moth using a temperaturedriven phenology model linked with geographic information systems. In Integrated Pest Management for the Potato Tuber Moth, Phthorimaea operculella Zeller - a Potato Pest of Global Importance. Trop. Ag. 20, Advances in Crop Research 10, ed. J. Kroschel and L. Lacey. Weikersheim: Margraf.

Stanev, M., and A. Kaitazov. 1962. Studies on the bionomics and ecology of the potato moth Gnorimoschema (Phthorimaea) operculella Zeller in Bulgaria and means for its control. Izv. nauch. Inst. Zasht. Rast. 3: 49-89.

Steinhaus, E.A. 1945. Bacterial infections of potato tuber moth larvae in an insectary. Journal of Economic Entomology 38: 718-719.

Stinsen, A.M., N.K. Zidack, G.A. Strobel, and B.J. Jacobson. 2003. Mycofumigation with Muscodor albus and Muscodor roseus for control of seedling diseases of sugar beet and Verticilium wilt of eggplant. Plant Disease 87: 1349-1354.

Sudeep, A.B., R. Khushiramani, S.S. Athawale, A.C. Mishra, and D. T. Mourya. 2005. Characterization of a newly established potato tuber moth (Phthorimaea operculella Zeller) cell line. Indian Journal of Medical Research 121: 159-163.

Summers, K.M., A.J. Howells, and N.A. Pyliotis. 1982. Biology of eye pigmentation in insects. Advances in Insect Physiology 16: 119-166.

Tamhankar, A.J., and M.R. Harwalkar. 1994. Comparision of a dry and a water trap for monitoring potato tubermoth, Phthorimaea operculella Zeller. Entomology 19: 163-165.

Traynier, R.M. 1975. Field and laboratory experiments on the site of oviposition by the potato moth. Bulletin of Entomological Research 65: 391-398.

Traynier, R.M. 1983. Influence of plant and adult food and fecundity of potato tuber moth, Phthorimaea operculella. Entomol. Experiment. Appl. 33: 145-154.

Trehan, K.N., and S.R. Bagal. 1944. Life history and bionomics of potato tuber moth Phthorimaea operculella Zell. (Lepidoptera: Gelechiidae). In Proceedings of the Indian National Science Academy 19: 176-187.

Trivedi, T.P., and D. Rajagopal. 1992. Distribution, biology, ecology and management of potato tuber moth, Phthorimaea operculella (Zeller) (Lepidoptera: Gelechiidae): a review. Tropical Pest Management 38: 279-285.

Underhill, G.W. 1926. Studies on the potato tuber moth during the winter of 1925-26. Bull: Va. Exp. Sta.

University-California. 2006. Integrated Pest Management for potatoes in the western United States. State wide integrated pest management program, Ag. and Nat. Resour. Pub. 3316, Western Regional Publication 011: 167.

Van der Goot, P. 1926. Brestrisding Van de aardappel-Knolrups in Goedangs. Korte Meded. Inst. Piziektenziekten 1: 17.

Varela, L.G., and E.A. Bernays. 1988. Behavior of newly hatched potato tuber moth larvae, Phthorimaea operculella Zell. (Lepidoptera: Gelechiidae), in relation to their host plants. Journal of Insect Behavior 1: 261-275.

Verma, R.S. 1967. Bionomics of Gnorimoschema operculella Zeller (Lepidoptera: Gelechiidae). Labdev Journal of Science and Technology 5: 318-324.

Voerman, S., and G.H.L. Rothschild. 1978. Synthesis of 2 components of sex-pheromone system of potato tuberworm moth, Phthorimaea operculella (Zeller) (Lepidoptera: Gelechiidae) and field experience with Them. Journal of Chemical Ecology 4: 531-542.

von Arx, R., and F. Gebhardt. 1990. Effects of a granulosis virus, and Bacillus thuringiensis on life-table parameters of the potato tubermoth, Phthorimaea operculella. Entomophaga 35: 151-159.

von Arx, R., J. Goueder, M. Cheikh, and A.B. Temime. 1987a. Integrated control of potato tubermoth Phthorimaea operculella (Zeller) in Tunisia. Insect Science and its Application 8: 989-994.

von Arx, R., J. Goueder, M. Cheikh, and A. Bentemime. 1987b. Integrated control of potato tubermoth Phthorimaea operculella (Zeller) in Tunisia. Insect Science and Its Application 8: 989-994.

von Arx, R., P.T. Ewell, J. Goueder, M. Essamet, M. Cheikh, and A.B. Temine. 1988. Management of the potato tuber moth by Tunisian farmers: A report of on-farm monitoring and a socioeconomic survey. The International Potato Center (CIP) in collaboration with Institut National de la Recherche Agronomique de Tunisie (INRAT).

Watmough, R.H., S.W. Broodryk, and D.P. Annecke. 1973. The establishment of two imported parasitoids of potato tuber moth (Phthorimaea operculella) in South Africa: (Copidosoma uruguayyensis, Apanteles subandinus). Entomophaga 18: 237-249.

Wearne, G.R. 1971. Improved mehotds for the production of parasites of the potato moth Phthorimaea operculella Zeller (Lepidoptera: Gelechiidae). Journal Australian Entomological Society 10: 61-63. 
Whilshire, E.P. 1957. The Lepidoptera of Iraq. Gov. Iraq Minist. Agric. 160.

Whiteside, E.F. 1980. Biological control of the potato tuber moth (Phthorimaea operculella) in South Africa by two introduced parasites (Copidosoma koehleri and Apanteles subandinus). Journal of Entomological Society Southern Africa 43: 239-255.

Whiteside, E.F. 1981. The results of competition between two parasites of the potato tuber moth, Phthorimaea operculella (Zeller) Apanteles subandinus, biological control, Copidosoma koehleri South Africa. Journal of Entomological Society Southern Africa 44: 359-365.

Whiteside, E.F. 1985. An adaptation to overwintering in the potato tuber moth, Phthorimaea operculella (Zeller) (Lepidoptera: Gelechiidae). Journal of Entomological Society Southern Africa 48: 163-167.
Worapong, J., G.A. Strobel, E.J. Ford, J. Li, G. Baird, and W.M. Hess. 2001. Muscodor albus anam. gen. et sp. nov. an endophte from Cinnamomum zeylanicum. Mycotaxon 79: 67-79.

Yathom, S. 1968. Phenology of the tuber moth, Gnorimoschema operculella Zell., in Israel in the spring. Israel Journal of Agricultural Research 18: 89-90.

Yathom, S. 1986. Phenology of the potato tuber moth (Phthorimaea operculella), a pest of potatoes and processing tomatoes in Israel. Phytoparasitica 17: 313-318.

Zagulyaev, A. 1982. Potato tuber moth, Phthorimaea operculella Zeller (Lepidoptera: Gelechiidae). EÁntomologicÏeskoe Obozrenie 61: $817-820$

Zeller, P.C. 1873. Beitrage Zur Kenntniss der nordamericanishchen Nachtfolter, besonders der Microlepidopteran. Verhandlungen der Zoologish-botanishchen Geselischaft in Wein 23: 262-263. 